\title{
Comparison of the Oil Quality of Light and Dark Walnuts under Different Storage Conditions
}

\author{
Aysun Yurdunuseven Yıldız and Hakan Karaca \\ Department of Food Engineering, Faculty of Engineering, Pamukkale University, 20160, Kinikli, Denizli, TURKEY
}

\begin{abstract}
The skin of the walnut kernels can get dark during the pre- and post-harvest stages of the production. Dark kernels are less palatable for most consumers but are still edible and maybe preferable, especially in the ground form, for industrial use. In this study, we investigated the differences between oil oxidation indexes, fatty acid and tocopherol compositions of the oils, total polyphenol contents and antioxidant capacities of the extracts of light and dark walnuts. In addition, we evaluated the effects of packaging under nitrogen and vacuum-packaging techniques and storage temperature on these characteristics of both light and dark walnuts during storage for 6 months. Peroxide values and free fatty acid contents of all samples were higher at the end of storage compared to initial values, being more noticeable at $20^{\circ} \mathrm{C}$ than at $4^{\circ} \mathrm{C}$. Increases in the free fatty acid contents were quite higher in dark walnuts than the light ones (6.1 and 3.1 fold, respectively) and the highest values of conjugated diene and peroxide were determined in the samples packaged under air and stored at $20^{\circ} \mathrm{C}$. Dark walnuts had lower total phenolic, $\alpha$ - and $\gamma$-tocopherol contents and antioxidant activities compared to the light ones. Total phenolic and tocopherol contents decreased over time. We conclude that due to the antioxidant compounds in the fruit, oxidation parameters of dark walnuts are still acceptable at the end of 6-month storage even in the packages with air and at non-refrigerated conditions.
\end{abstract}

Key words: pellicle color, darkening, ground walnut, storage condition, lipid oxidation

\section{Introduction}

Walnut (Juglans regia L.) is one of the most prominent nuts with its unique flavor and high economic value. World production of in-shell walnuts is around 4.5 million tons per year and the USA, Iran, China and Turkey are the leading producers of walnut ${ }^{1)}$. The walnut kernel consists of an embryo and a pellicle. The seed is further surrounded by a hard shell and a green fleshy hull. The quality of walnut depends on the cultivar, climate, harvest, handling and storage conditions. Walnut fruit is rich in protein, fiber, minerals, phenolics, tocopherols and other antioxidant compounds $^{2)}$. Lipids are the most abundant component of the walnut and health benefits of the fruit are mainly attributed to its poly-unsaturated fatty acid content ${ }^{3)}$. However, these poly-unsaturated fatty acids make the fruit very susceptible to oxidative deterioration reactions.

Antioxidant compounds in the walnut, mostly found in the pellicle around the kernel, protect the fruit against oxidation ${ }^{4}$. Any disruption of the integrity of the pellicle results in increased susceptibility of the kernel against oxidation. Ortiz et $a l .{ }^{5)}$ studied the effect of walnut pellicle in- tegrity on quality parameters of two different walnut cultivars. Increased pellicle damage resulted in reduced contents of phenolics and increased free fatty acid values. The authors also observed that surface colors were darker in kernels with damaged pellicle compared to undamaged ones. Darkening of the walnut pellicle can occur depending on other factors as well. For instance, late harvest ${ }^{6)}$ and physical damage caused by walnut husk fly $^{7)}$ were reported to cause darkening of the kernel due to juice released from the hull and leaked through the shell. Koyuncu et $a l^{8)}{ }^{8}$ evaluated the effects of the length of time that the hull remains on the shell on kernel color of the walnuts. They hulled walnuts at harvest time, and 3 and 5 days after harvest. The authors observed that a delay of 3-5 days between harvest and hulling time caused darker kernel colors. They also reported that kernel darkening was more noticeable in the walnuts dried in the shadow compared to sun dried walnuts. In the literature, there are several studies reporting that kernel darkening depends on the temperature chosen for drying walnuts ${ }^{9,10)}$ and a temperature range of $32-43^{\circ} \mathrm{C}$ was recommended for drying process to obtain the

\footnotetext{
*Correspondence to: Aysun Yurdunuseven Yıldız, Department of Food Engineering, Faculty of Engineering, Pamukkale University, 20160, Kinikli, Denizli, TURKEY

E-mail: ayurdunuseven@pau.edu.tr

Accepted January 19, 2021 (received for review September 22, 2020)
}

Journal of Oleo Science ISSN 1345-8957 print / ISSN 1347-3352 online

http://www.jstage.jst.go.jp/browse/jos/ http://mc.manusriptcentral.com/jjocs 


\section{A. Y. Ylldız and H. Karaca}

required quality characteristics including ideal kernel color $^{11)}$.

In fact, darkening of walnut kernel is a typical example of enzymatic browning in which phenolic compounds serve as substrates. Zhang et al. ${ }^{12)}$ identified potential genes in Chinese walnuts associated with enzymatic browning. Oxidizable phenolic compounds, such as $O$-diphenols, are transformed to brownish o-quinones as a result of enzymatic browning reactions. These reactions are more likely to occur in fresh walnuts compared to dried ones due to relatively higher moisture content of the former ${ }^{8)}$. Therefore, fresh walnuts have to be dried as soon as possible to a moisture content of $5-8 \%$ to minimize darkening of the kernels ${ }^{9)}$.

As a matter of fact, dark walnuts are perhaps not preferable but are still edible, while moldy and insect-invaded walnuts are almost worthless. Dark walnuts are classified as "second quality" ${ }^{13)}$ and can be sold at relatively lower prices than the first quality products ${ }^{14)}$. They are generally chopped or ground and used as an ingredient of bakery products, chocolate, etc. or can be used for walnut oil production for economic choices. In recent years, quality attributes of dark walnuts from different varieties have been compared with those of light ones and significant differences in important chemical and sensory properties have been reported $^{7,15,16)}$.

The effects of different packaging techniques and storage conditions on the oxidation values of inshell walnuts, walnut kernels, ground walnut and walnut oil have been evaluated by other authors ${ }^{17-21)}$. It can be concluded from all these studies that reducing oxygen content in the package and refrigerated storage conditions can slow down the oxidation reactions. Mexis et $a l .{ }^{22)}$ demonstrated that temperature was the most important parameter for oxidation reactions occurred in the walnuts and other determinative factors were oxygen availability and lighting conditions. Christopoulos and Tsantili ${ }^{23)}$ showed that walnuts became darker and their phenolic and antioxidant contents decreased during storage. They also determined that packaging under nitrogen $\left(\mathrm{N}_{2}\right)$ and carbon dioxide $\left(\mathrm{CO}_{2}\right)$ and refrigerated storage conditions were effective on limiting both antioxidant loss and darkening of the walnut. López et $a l .{ }^{24)}$ reported that walnut type is also a crucial factor on darkening of the kernels during refrigerated storage of the walnut fruit.

As described above, the effect of packaging and storage conditions on ongoing natural processes including darkening of the kernels have been studied. However, there are no reports investigating the storage period of the walnut kernels that already have a dark color at the beginning of the storage. In addition, although they are sold in the market and used as an ingredient of many food products, the shelf life of these dark walnuts has not yet been reported. Furthermore; the effects of packaging techniques and storage conditions on quality parameters were well defined for first quality walnuts, but have not yet been revealed for dark ones.

It is known that phenolics on the pellicle have a protective role in oxidation reactions ${ }^{25,26)}$. The amount of phenolics decreases as the oxidation reactions proceed ${ }^{27)}$. Decrease in phenolics can cause a decrease in resistance against lipid oxidation with a concurrent darkening of the pellicle of the kernel. Since these reactions are quite complicated and probably trigger each other, in our opinion, they should be separately investigated in light and dark walnut samples.

The purpose of this study was to compare ground light and dark walnut kernels in terms of oil oxidation indexes, fatty acid and tocopherol compositions of their oils, total polyphenol contents and antioxidant capacities of their extracts. We also investigated the effects of packaging under nitrogen and vacuum-packaging techniques on quality parameters of these samples during storage for 6 months at 4 and $20^{\circ} \mathrm{C}$ and determined if there are any differences between the oxidation status of light and dark walnuts.

\section{Materials and Methods}

\subsection{Materials}

The cultivar of the walnuts used in the study were 'Sebin', one of the most widely planted cultivar in Turkey. Fruits were harvested from trees in an orchard located in Acipayam region in Denizli, Turkey, in September 2018. The fruits were hulled and dried in open air for 4 days to a moisture content of about 3.5\%. Dried walnuts were stored at $4{ }^{\circ} \mathrm{C}$ for further experiments. Chemicals used in the study were of analytical grade or higher purity. Anhydrous sodium sulfate, chloroform, potassium hydroxide, sodium hydroxide, sodium carbonate, 2,2-diphenyl-1-picrylhydrazyl (DPPH), 6-hydroxy-2,5,7,8-tetramethylchroman-2-carboxylic acid (trolox) and Folin-Ciocalteau reagent were purchased from Sigma-Aldrich (St. Louis, MO, USA). Starch and gallic acid were purchased from Merck(Darmstadt, Germany). Potassium iodide, sodium thiosulfate, 2-propanol and methanol(chromatography grade) were purchased from Carlo Erba(Milan, Italy). Isooctane, methanol (reagent grade) and acetic acid were purchased from Isolab Inc. (Akron, OH, USA). Ethanol and $n$-hexane were purchased from Tekkim Chemicals (Istanbul, Turkey).

\subsection{Methods}

\subsubsection{Categorization, grinding, packaging and storage}

The shells of the walnuts were cracked using a nutcracker and removed manually. The walnut kernels were visually inspected and defective kernels (damaged, shrivelled and moldy ones) were discarded. The surface color of the remaining kernels were measured (three measurements for 


\section{Oil Quality of Light and Dark Walnuts}

each kernel) using a portable colorimeter (CSM 1, PCE Instruments, Southampton, UK) and $\mathrm{L}^{*}, \mathrm{a}^{*}$ and $\mathrm{b}^{*}$ values were determined. Measuring aperture of the colorimeter was $4 \mathrm{~mm}$ and the light source was D65. Chroma and hue angle values were calculated from $\mathrm{a}^{*}$ and $\mathrm{b}^{*}$ values according to the following equations:

$$
\begin{aligned}
& \text { Chroma }=\left[\left(a^{*}\right)^{2}+\left(b^{*}\right)^{2}\right]^{1 / 2} \\
& \text { Hue angle }=\arctan \left(b^{*} / a^{*}\right)
\end{aligned}
$$

Categorization of the kernels was performed using a system developed by Brawner and Warmund ${ }^{6)}$ with a slight modification. Accordingly, LCH sums $\left(\mathrm{L}^{*}+\right.$ chroma + hue angle) were calculated and the kernels with a LCH sum $\geq$ 75 were described as 'light' and the kernels with a LCH sum $\leq 50$ were described as 'dark'. Light and dark walnuts were separately ground using a coffee grinder (King, K-444 Grindex, Istanbul, Turkey). The ground walnut samples were sieved through stainless steel sieves to obtain homogeneous particles with sizes in the range of 1-4 mm. Then, $75 \mathrm{~g}$ of the ground samples were weighed into a filter bag and the bag was placed into laminated plastic pouches (polyethylene + polyamide + ethylene vinyl alcohol + polyamide + polyethylene, $25 \times 25 \mathrm{~cm}$, KRCPACK, Istanbul, Turkey). Based on technical data sheet provided by the supplier; thickness of the bag was $65 \pm 5 \mu \mathrm{m}$, oxygen transfer rate $\left(23^{\circ} \mathrm{C}\right.$ and $\left.0 \% \mathrm{RH}\right)$ and water transfer rate $\left(38^{\circ} \mathrm{C}\right.$ and $90 \% \mathrm{RH})$ were less than $3 \mathrm{~cm}^{3} \mathrm{~m}^{-2} \mathrm{~d}^{-1}$ and $12 \mathrm{~cm}^{3} \mathrm{~m}^{-2}$ $\mathrm{d}^{-1}$, respectively. Packaging of the samples were performed using a packaging equipment(DZ-260, Seles, Wenzhou Xingye Machinery Equipment Co. Ltd., Beijing, China). Vacuum-packaging was carried out by setting the vacuum at $90 \mathrm{kPA}$. Packaging under nitrogen was performed by evacuating the air inside the bag by vacuum, introducing the nitrogen gas into the bag and finally heat-sealing of the package. The packages were stored for 6 months in the dark either in a refrigerated incubator set at $4{ }^{\circ} \mathrm{C}$ or in a climatized room at $20^{\circ} \mathrm{C}$. Average temperature values were recorded as $4.3 \pm 0.5^{\circ} \mathrm{C}$ and $20.5 \pm 1.4^{\circ} \mathrm{C}$ in the incubator and the room, respectively. Four samples for each treatment were withdrawn monthly and subjected to the analyses described below.

2.2.2 Measurement of gas composition in the packages

Gas composition in the packages was determined just after packaging and on each sampling day using a portable gas analyzer (Dansensor, Checkpoint, PBI, Ringsted, Denmark) on two replicates. The analyzer drew a gas sample from the package atmosphere via a syringe needle and detected the oxygen and carbondioxide concentrations. The nitrogen concentration was calculated by subtracting the sum of these concentrations from $100 \%$.

\subsubsection{Oil extraction from ground walnut samples}

Walnut samples from each sampling day (75 g) were further ground using a mortar and pestle and transferred to an erlenmeyer flask. Then, approximately $375 \mathrm{~mL} n$ hexane was added and the content of the flask was homogenized at $14000 \mathrm{rpm}$ for 1 min using a homogenizer (IKA T18 Ultra-Turrax, Staufen, Germany). The flasks were placed on an orbital shaker(OS-20, Boeco, Hamburg, Germany) and shaken at $140 \mathrm{rpm}$ for $2 \mathrm{~h}$ at room temperature. After this period, the homogenate was filtered through a layer of anhydrous sodium sulfate and the filtrate was collected into a $250 \mathrm{~mL}$ round bottom flask. The remaining walnut sample was re-extracted with the same procedure described above. The extracts were combined and $n$-hexane was evaporated at $40^{\circ} \mathrm{C}$ under vacuum using a rotary evaporator (Büchi Rotavapor R-114, Flawil, Switzerland). The walnut oil and the defatted walnut sample were separately kept at $-20^{\circ} \mathrm{C}$ until use in the analysis.

\subsubsection{Determination of free fatty acid and acid values}

Free fatty acid (FFA) values of the oil samples were determined according to the Official Method Ca $5 \mathrm{a}-40$ of the American Oil Chemical Society $^{28)}$. Accordingly, $1 \mathrm{~g}$ of oil sample was dissolved in $10 \mathrm{~mL}$ of ethanol and this solution was titrated with the standardized sodium hydroxide solution in the presence of phenolphthalein as an indicator. FFA value of the sample was calculated according to the following equation:

$$
F F A \%(\text { as oleic acid })=(V \times N \times 28.2) / m
$$

where; $\mathrm{V}$ is the volume $(\mathrm{mL})$ of the $\mathrm{NaOH}$ solution used in the titration, $\mathrm{N}$ is the normality of the $\mathrm{NaOH}$ solution and $\mathrm{m}$ is the weight $(\mathrm{g})$ of the sample.

The acid value is expressed as the number of milligrams of potassium hydroxide required to neutralize the free fatty acids present in one gram of oil sample. The acid value was determined by multiplying the value obtained for the percent free fatty acids (FFA) by $1.99^{28)}$.

The acid value was calculated as:

$$
\text { Acid value }\left(\mathrm{mg} \mathrm{KOH} \mathrm{g}^{-1}\right)=1.99 \times F F A(\%)
$$

2.2.5 Determination of peroxide value

Peroxide values of the oil samples were determined according to the AOCS Official Method Cd 8-53 ${ }^{29)} .1 \mathrm{~g}$ of walnut oil was weighed in an erlenmeyer flask and $6 \mathrm{~mL}$ of acetic acid-chloroform mixture (60:40, v/v) was added. This mixture was reacted with a saturated potassium iodide solution $(0.1 \mathrm{~mL})$ in the dark for $1 \mathrm{~min}$. Afterwards, the resulting solution was titrated with a sodium thiosulfate solution in the presence of starch solution as an indicator. Peroxide value was expressed as milliequivalents of active oxygen per kilogram of oil (meq $\mathrm{O}_{2} \mathrm{~kg}^{-1}$ oil). Results were calculated according to the following equation:

$$
\text { Peroxide value }\left(\text { meq } \mathrm{O}_{2} \mathrm{~kg}^{-1}\right)=(S-B) \times N \times 1000 / m
$$

where; $\mathrm{S}$ and $\mathrm{B}$ are the volumes $(\mathrm{mL})$ of the sodium thiosulfate solution used in the titration of the sample and blank, respectively, $\mathrm{N}$ is the normality of the sodium thiosulfate 


\section{A. Y. Ylldız and H. Karaca}

solution and $\mathrm{m}$ is the weight $(\mathrm{g})$ of the sample.

2.2.6 Determination of conjugated diene and triene contents

The conjugated diene and triene contents were determined by measuring the absorbance of the samples prepared with isooctane (1\%, w/v) at 232 and $270 \mathrm{~nm}$ using a spectrophotometer (PG Instruments, Lutterworth, UK) according to the AOCS Official Method Ch5-91 ${ }^{30)}$. Results were calculated using the following equation:

$$
K_{\lambda}=A_{\lambda} /(c \times L)
$$

where; $K_{\lambda}$ is the specific extinction at the wavelength tested (232 nm or $270 \mathrm{~nm}$ ), $\mathrm{A}_{\lambda}$ is the absorbance measured at the wavelength tested ( $232 \mathrm{~nm}$ or $270 \mathrm{~nm}$ ); c is the concentration of the solution (g per $100 \mathrm{~mL}$ ), and L is the path length of the quartz cuvette $(\mathrm{cm})$.

2.2.7 Determination of total phenolic content and antioxidant activity

Extraction of phenolics and other antioxidant compounds from defatted walnut sample was done according to the method described by Bakkalbaşi et $a l .{ }^{31)}$ with a slight modification. A portion $(0.25 \mathrm{~g})$ of the sample was weighed in an erlenmeyer flask and $10 \mathrm{~mL}$ of methanol:water mixture (80:20, v/v) was added. After homogenization(IKA T18 Ultra-Turrax), the flask was shaken on the orbital shaker at $200 \mathrm{rpm}$ for $2 \mathrm{~h}$ at room temperature. Then, the flask content was transferred to a polypropylene tube and centrifuged at $7031 \times g$ for $10 \mathrm{~min}$ (Nuve, NF 800R, Nuve, Ankara, Turkey). The supernatant was transferred to an amber vial and the residue was re-extracted using the procedure explained above. The extracts were combined in a polypropylene tube and used for total phenolic content and antioxidant activity determination.

Total phenolic content in the samples was determined according to the Folin-Ciocalteu (FC) method as described by Singleton $e t a l .{ }^{32)}$ with a slight modification. FC solution $(1: 10, \mathrm{v} / \mathrm{v})$ and sodium carbonate solution $\left(75 \mathrm{~g} \mathrm{~L}^{-1}\right)$ were prepared with distilled water. Three hundred $\mu \mathrm{L}$ of the extract and $1500 \mu \mathrm{L}$ of FC solution were put into a $15-\mathrm{mL}$ polypropylene tube and the tube was vigorously mixed with a vortex mixer. Afterwards, $1200 \mu \mathrm{L}$ of sodium carbonate solution was added to the tube and the tube was vigorously mixed again. After holding the tube in the dark for $2 \mathrm{~h}$, the absorbance was measured at $760 \mathrm{~nm}$ by the spectrophotometer (Multiskan GO Microplate Spectrophotometer, Thermo Scientific, Finland). Standard solutions of gallic acid were prepared in distilled water and a calibration curve (5-100 $\left.\mathrm{mg} \mathrm{L}^{-1}\right)$ was drawn. Total phenolic content of the sample was determined using this curve and expressed as mg gallic acid equivalent (GAE) per g defatted walnut.

Antioxidant activity of the samples was determined using DPPH method as described by Thaipong et al. ${ }^{33)}$. A stock solution of DPPH was prepared in methanol and the absorbance of this solution at $515 \mathrm{~nm}$ was adjusted to 1.1 \pm 0.02 by diluting with methanol. One hundred and fifty $\mu \mathrm{L}$ of the extract and $2850 \mu \mathrm{L}$ of DPPH stock solution was put into a $15-\mathrm{mL}$ polypropylene tube and the tube was vigorously mixed with a vortex mixer. After holding the tube in the dark for $1 \mathrm{~h}$, the absorbance was measured at $515 \mathrm{~nm}$ by the spectrophotometer. Trolox, a water-soluble analogue of $\alpha$-tocopherol, was used as a standard for antioxidant activity. An exact amount of trolox was weighed in a $10-\mathrm{mL}$ volumetric flask and dissolved in $1 \mathrm{~mL}$ ethanol. Then, the volume was adjusted to $10 \mathrm{~mL}$ with distilled water. This solution was used to draw a calibration curve covering the range of $10-50 \mu \mathrm{M}$ trolox. Antioxidant activity of the sample was determined using this curve and expressed as mmol trolox equivalent (mmol TEAC) per g defatted walnut.

2.2.8 Determination of tocopherol contents

Tocopherols were determined according to the AOCS Official Method Ce 8-89 $9^{34)}$ with a slight modification. Briefly, $0.25 \mathrm{~g}$ of oil samples was diluted with $1 \mathrm{~mL}$ of 2-propanol, filtered through a microfilter with a pore size of $0.45 \mu \mathrm{m}$ (Chromafil Xtra PTFE-45/25, Macherey-Nagel, Duren, Germany) and injected into a high pressure liquid chromatography (HPLC, Shimadzu LC-20AD, Kyoto, Japan). Analytical column was Zorbax Eclipse XDB-C18 column (Agilent Technologies, $250 \mathrm{~mm} \times 4.6 \mathrm{~mm}$ i.d., $5 \mu \mathrm{m}$ particle diameter, Santa Clara, USA), column temperature was $25^{\circ} \mathrm{C}$ and the injection volume was $20 \mu \mathrm{L}$. The mobile phase was HPLC grade methanol with a flow rate of $1 \mathrm{~mL}$ $\min ^{-1}$. Detection was carried out at $289 \mathrm{~nm}$ for $\alpha$-tocopherol and $297 \mathrm{~nm}$ for $\delta$-tocopherol and $\gamma$-tocopherol using a photodiode array detector (Shimadzu SPD-M20A). Standard solutions of $\alpha$-, $\delta$ - and $\gamma$-tocopherol were separately prepared in ethanol using analytical standards of these compounds (Supelco, Sigma-Aldrich, Bellefonte, CA, USA) and 6-point calibration curves $\left(0.25-25 \mathrm{mg} \mathrm{L}^{-1}\right.$ for $\alpha$-tocopherol, 1-50 $\mathrm{mg} \mathrm{L}^{-1}$ for $\delta$-tocopherol and 5-500 $\mathrm{mg} \mathrm{L}^{-1}$ for $\gamma$-tocopherol) were drawn. Quantification of the tocopherols in the samples was performed using these curves. 2.2.9 Determination of fatty acid composition

Fatty acid methyl esters (FAMEs) were prepared according to the AOCS Official Method Ce 2-66 ${ }^{35)}$. Accordingly, 0.2 $\mathrm{g}$ of the oil sample was dissolved in $2 \mathrm{~mL}$ of $n$-hexane and treated with $0.2 \mathrm{~mL}$ of methanolic potassium hydroxide solution. After mixing vigorously and waiting for phase separation (30 min), clear upper layer was taken with a microsyringe and injected into the injection port of the gas chromatography apparatus (Agilent 7820A, Santa Clara, USA) equipped with flame ionization detector. FAMEs were separated on a capillary column (Agilent Technologies, DBFATWAX UI, $30 \mathrm{~m} \times 0.25 \mathrm{~mm}$ i.d., $0.25 \mu \mathrm{m}$ film thickness, Santa Clara, USA). The injection volume was $1 \mu \mathrm{L}$ with a split ratio of 1:100 and the carrier gas was hydrogen at a flow rate of $1.4 \mathrm{~mL} \mathrm{~min}^{-1}$. The column temperature was 
programmed to $50^{\circ} \mathrm{C}$ for 2 min and increased to $174^{\circ} \mathrm{C}$ for $14 \mathrm{~min}$ at $50^{\circ} \mathrm{C} \mathrm{min}^{-1}$ and then increased to 215 for $25 \mathrm{~min}$ at $2^{\circ} \mathrm{C} \mathrm{min}^{-1}$. The temperatures of the injector and the detector were 250 and $280^{\circ} \mathrm{C}$, respectively. Peaks in the chromatogram were identified by comparison of their retention times with those of standard methyl esters (Supelco 37-component FAME Mix, Bellefonte, PA, USA) .

2.2.10 Statistical analysis

An analysis of variance (ANOVA) was employed to determine significant differences among means using a statistical package program (MINITAB v. 13, MINITAB Inc., State College, PA, USA). Significant differences among means were identified by Tukey's Multiple Range Test $(p \leq 0.05)$ using MSTAT-C statistical software (MSTAT 1991, Michigan State University, MI, USA).

\section{Results and Discussion}

\subsection{Gas compositions in the packages of ground light and dark walnuts}

Gas composition percentages in the packages of ground light and dark walnuts during storage at 4 and $20^{\circ} \mathrm{C}$ are shown in Table 1. $\mathrm{O}_{2}, \mathrm{CO}_{2}$ and $\mathrm{N}_{2}$ concentrations ranged between $19.3-21.2 \%, 0.0-0.7 \%$ and $78.9-80.1 \%$, respectively, in packages with air during 6-month storage. The corresponding concentrations were $0.0-0.3 \%, 0.0-0.1 \%$ and $99.7-100.0 \%$, respectively, in samples packaged with $\mathrm{N}_{2}$. Storage temperature did not have a marked impact on gas composition in the packages. The slight and negligible changes in the gas composition of the packages might be attributed to the high barrier properties of the packaging material we used. Laminated films with an "ethylene vinyl alcohol" layer were reported to have high barrier proper$\operatorname{ties}^{36)}$ and to be effective in retaining the atmosphere in walnut $^{37)}$ and almond ${ }^{38)}$ packages.

\subsection{Free fatty acid and acid values of ground light and dark walnuts}

FFAs are released by decomposition of triacylglycerols as a result of chemical or enzymatic reactions which may be triggered by heat, light and moisture ${ }^{39)}$. FFA value is used as an indicator of lipid hydrolysis and stability of the oil. Although there is no a clearly stated threshold for FFA value for walnuts, a value of $0.6 \%$ oleic acid is generally recognized as "acceptable" by the walnut industry ${ }^{19,40)}$. FFA values of light and dark walnuts packaged with different techniques and stored for 6 months at 4 and $20^{\circ} \mathrm{C}$ are shown in Figs. $1 \mathrm{a}$ and $1 \mathrm{~b}$, respectively. The initial FFA values of both light and dark walnuts were $0.19 \%$ oleic acid (with standard deviations of 0.02 and 0.01 , respectively). Our results showed that FFA values of both light and dark walnuts increased during storage. Increase in FFA values in both light and dark walnuts were lower at $4^{\circ} \mathrm{C}$ than that at $20^{\circ} \mathrm{C}$ on all sampling days. At the end of the 6 -month storage, FFA values of light walnuts packaged under air, nitrogen and vacuum-packaged and stored at $4{ }^{\circ} \mathrm{C}$ were 0.24 , 0.26 and $0.23 \%$ oleic acid, respectively, which were all close to initial values. However, these values were recorded as $0.58,0.55$ and $0.59 \%$ oleic acid, respectively, for the samples stored at $20^{\circ} \mathrm{C}$. Therefore, it is clearly seen that increasing storage temperature accelerates the biochemical reactions in the walnuts and increases the FFA values. High FFA values were also reported in previous studies for walnuts ${ }^{19)}$ and almonds ${ }^{41)}$ stored at high temperatures. In the present study, although FFA values of samples stored at $20^{\circ} \mathrm{C}$ was close to the border of acceptability $(0.6 \%$ oleic acid), yet, FFA values of light walnuts were all under the acceptable point for each case.

Increases in FFA values at both storage temperatures were quite higher in dark walnuts than those in light ones. For example, at the end of storage at $20^{\circ} \mathrm{C}$, FFA values increased 2.9-3.1 and 4.5-6.1 fold compared to the initial value in light and dark walnuts, respectively. FFA values of light walnuts were low during storage at both temperatures. On the other hand, FFA values of dark walnuts were low and quite stable during storage at $4{ }^{\circ} \mathrm{C}$, but gradually increased -to over $1 \%$ oleic acid in some cases- during storage at $20^{\circ} \mathrm{C}$. FFA values of the walnuts packaged under nitrogen were significantly $(p<0.05)$ lower except the light ones stored at $4^{\circ} \mathrm{C}$. Then, it can be concluded that there is no need for packaging under nitrogen if the conditions (kernel color, storage temperature, etc.) are favorable. However, if dark walnuts are stored or storage temperature is not low enough, packaging under nitrogen can be used as an effective method to minimize FFA increase. Although statistically not significant, FFA values of vacuum-packaged light and dark walnuts were higher compared to other samples at the end of storage at $20^{\circ} \mathrm{C}$. In our opinion, walnut particles might be compressed during vacuum application and oil could leak from the damaged cells of the particles. Oil leaked out of the cell could get involved in enzymatic and chemical reactions, and therefore the FFA value could increase ${ }^{42)}$.

Acid value is dependent on FFA value and an increase in the FFA content is directly proportional to an increase in the acid value. The acid value characterizes the destruction of the quality of the oil stemming from the hydrolysis of triacylglycerol. The maximum acceptable level for acid value is $4 \mathrm{mg} \mathrm{KOH} \mathrm{g}^{-1}$ oil according to the Codex Alimentarius Commission standard for cold-pressed and virgin oils ${ }^{43)}$. Acid values of light and dark walnuts packaged with different techniques and stored for 6 months at 4 and $20^{\circ} \mathrm{C}$ are shown in Figs. $2 \mathrm{a}$ and $2 \mathrm{~b}$, respectively. The initial acid values of light and dark walnuts were $0.38 \pm 0.03$ and 0.39 $\pm 0.02 \mathrm{mg} \mathrm{KOH} \mathrm{g}^{-1}$, respectively. In the present study during storage, both light and dark walnut samples had low acid values $\left(0.38-2.28 \mathrm{mg} \mathrm{KOH} \mathrm{g}^{-1}\right)$ which are within the 


\section{A. Y. Ylldız and H. Karaca}

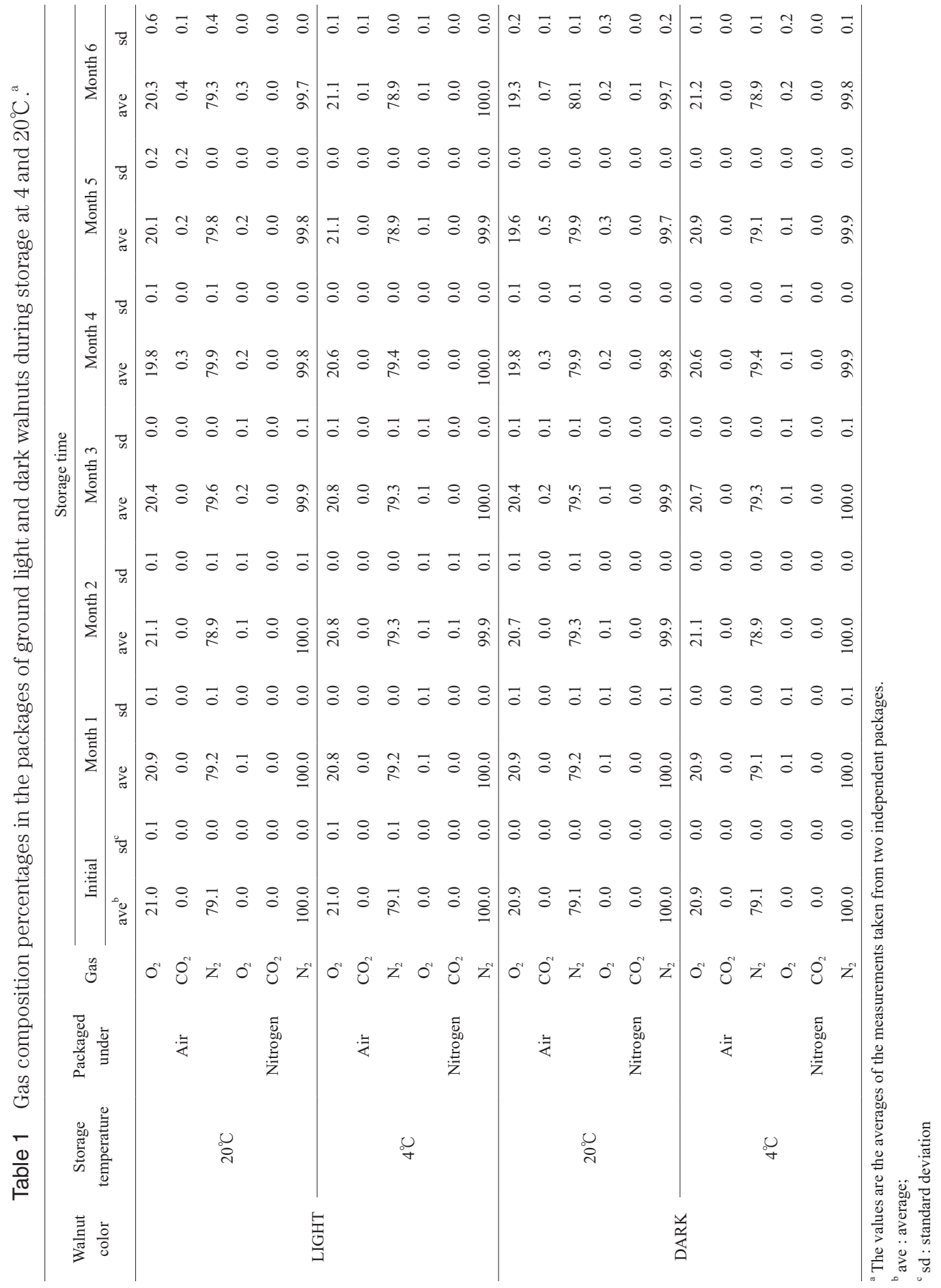


a

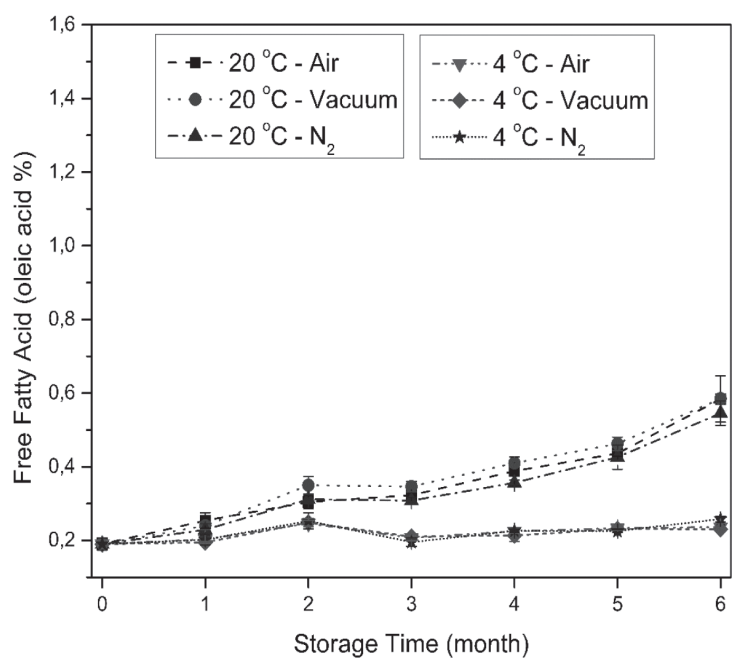

b

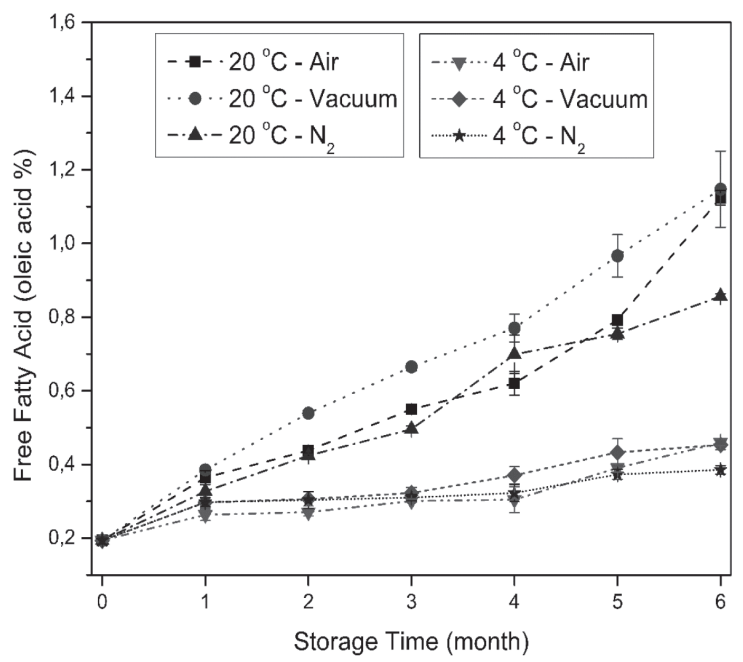

Fig. 1 Free fatty acid values of ground walnuts packaged with different techniques during storage at 4 and $20^{\circ} \mathrm{C}$ (a: light walnuts, b: dark walnuts). The values are the averages ( \pm standard deviations) of the results of four independent samples.

acceptable limit of $4 \mathrm{mg} \mathrm{KOH} \mathrm{g}^{-1}$. As can be seen from the Figs. $2 a$ and $2 b$, the acid values of the walnuts increased significantly as a function of time. At the end of storage at $4^{\circ} \mathrm{C}$, acid values were $0.47-0.51 \mathrm{mg} \mathrm{KOH} \mathrm{g}^{-1}$ and $0.77-0.91$ $\mathrm{mg} \mathrm{KOH} \mathrm{g}^{-1}$ in light and dark walnuts, respectively. However, at the end of storage at $20^{\circ} \mathrm{C}$, the corresponding acid values were $1.09-1.16 \mathrm{mg} \mathrm{KOH} \mathrm{g}^{-1}$ and $1.70-2.28 \mathrm{mg}$ $\mathrm{KOH} \mathrm{g}^{-1}$, respectively. Increase in acid values were more noticeable in dark walnuts than in the light ones. The acid values of both light and dark walnuts stored at $20^{\circ} \mathrm{C}$ were significantly higher than those of $4^{\circ} \mathrm{C}$ during storage $(p<$ 0.05 ). In addition, the acid values of the light walnuts were significantly lower than the dark ones under all storage conditions $(p<0.05)$. Acid values of dark walnuts were sig- a

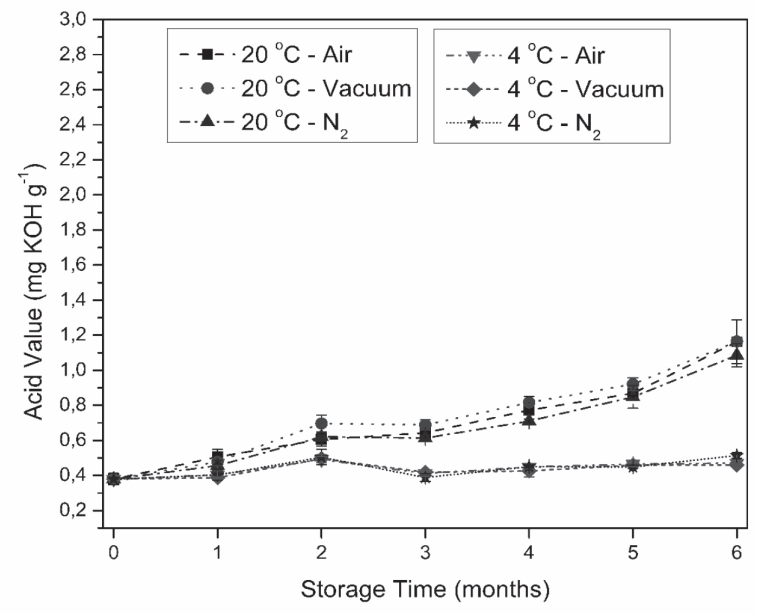

b

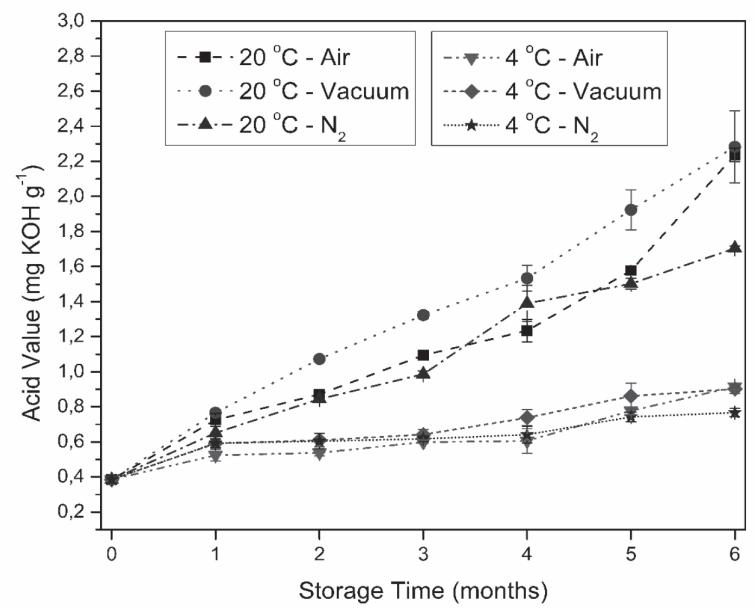

Fig. 2 Acid values of ground walnuts packaged with different techniques during storage at 4 and $20^{\circ} \mathrm{C}$ (a: light walnuts, b: dark walnuts). The values are the averages ( \pm standard deviations) of the results of four independent samples.

nificantly lower when stored under nitrogen at both temperatures.

\subsection{Peroxide values of ground light and dark walnuts}

Peroxides are the primary products of lipid oxidation. These peroxides are then transformed into various secondary products some of which cause undesired changes such as rancidity and off-flavor in the product. Although there is not a standard numerical threshold determined for the peroxide value for walnuts, different values have been suggested by the researchers. For instance, peroxide value should be lower than 1 meq $\mathrm{O}_{2} \mathrm{~kg}^{-1}$ according to private walnut companies ${ }^{19)}$, however, in the study conducted by Buransompob et $a l .{ }^{44)}$, it was stated that walnuts with peroxide values less than 3 meq $\mathrm{O}_{2} \mathrm{~kg}^{-1}$ are acceptable. Furthermore, walnuts with even 10 meq $\mathrm{O}_{2} \mathrm{~kg}^{-1}$ of peroxide value were identified as consumable according to the 
a

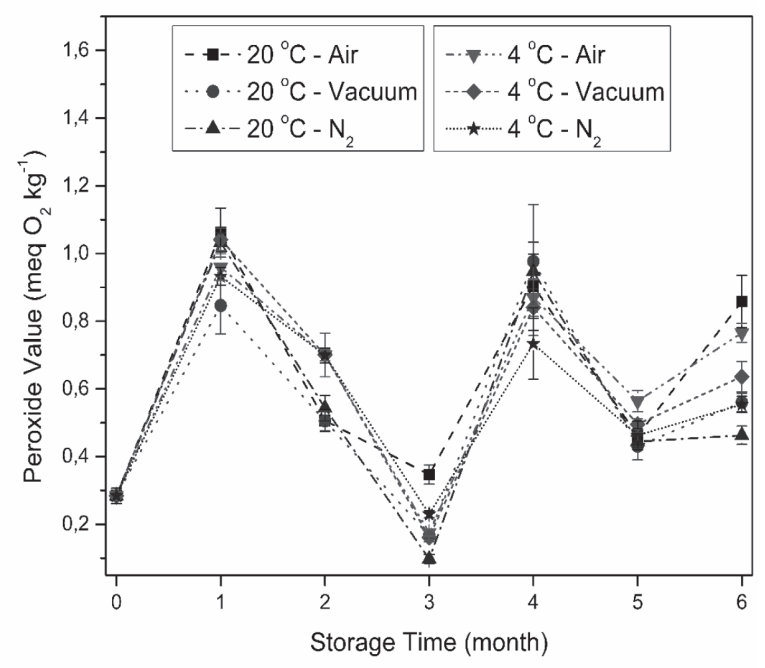

b

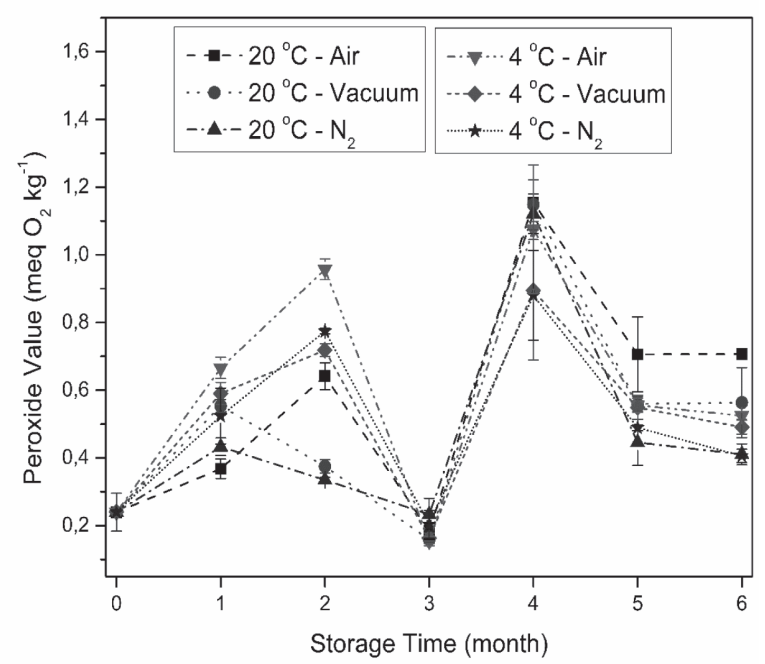

Fig. 3 Peroxide values of ground walnuts packaged with different techniques during storage at 4 and $20^{\circ} \mathrm{C}$ (a: light walnuts, b: dark walnuts). The values are the averages ( \pm standard deviations $)$ of the results of four independent samples.

results of sensory panels in the study of Mexis et $a{ }^{22)}$. Peroxide values of light and dark walnuts packaged with different techniques and stored for 6 months at 4 and $20^{\circ} \mathrm{C}$ are shown in Figs. $3 \mathrm{a}$ and $3 \mathrm{~b}$, respectively. The initial peroxide values of light and dark walnuts were $0.28 \pm 0.02$ and $0.24 \pm 0.06$ meq $\mathrm{O}_{2} \mathrm{~kg}^{-1}$, respectively. In general, all stored walnut samples had similar changing trends in terms of peroxide values. Peroxide values increased at the end of first month, then decreased to a minimum at the end of third month of storage. Then, peroxide values increased again at the end of fourth month. It can be concluded from these findings that the degradation rate was faster than the formation rate of peroxides during the third month of storage. Similar fluctuations in peroxide values of other nuts were also observed by other researchers ${ }^{45-47}$. It can be due to the unstable nature of the peroxides and their simultaneous formation and decomposition in vegetable ${ }_{\text {oils }}{ }^{48}$. According to Ding et $a l .{ }^{49)}$, increases and decreases observed in peroxide values could be related to unstable lipoxygenase activity. On the other hand, consistent increases in peroxide values of hazelnuts ${ }^{50)}$ and almonds ${ }^{51)}$ were observed during storage. It is obvious that this discrepancy could arise from differences among cultivars, pre- and postharvest applications, storage conditions, etc. Peroxide values in all samples were significantly higher $(p<0.05)$ at the end of 6-month storage than that at the beginning. Different packaging techniques caused some differences in peroxide values of both light and dark walnuts, but these differences were not statistically significant $(p>0.05)$. Similar findings were reported for almonds ${ }^{52)}$ and peanuts ${ }^{53)}$ packaged under nitrogen. According to our results, storage temperature has a strong effect on peroxide values of the walnuts. We determined that peroxide values of the walnuts ranged from 0.15 to 1.08 meq $\mathrm{O}_{2} \mathrm{~kg}^{-1}$ and from 0.10 to 1.15 meq $\mathrm{O}_{2} \mathrm{~kg}^{-1}$ when stored at 4 and $20^{\circ} \mathrm{C}$, respectively. Bakkalbasi et $a l .{ }^{31)}$ stored vacuum-packaged shelled walnuts at 3 different temperatures for 12 months. They determined that peroxide values of the walnuts were low and almost stable at 10 and $20^{\circ} \mathrm{C}$, however, increased systematically during storage at $30^{\circ} \mathrm{C}$. Villarreal-Lozoya et $a l .{ }^{54)}$ stored pecan walnuts and at $40^{\circ} \mathrm{C}$ for 134 days and determined that peroxide values reached up to 2 meq $\mathrm{O}_{2} \mathrm{~kg}^{-}$ 1 .

The highest peroxide value $\left(1.15\right.$ meq $\left.\mathrm{O}_{2} \mathrm{~kg}^{-1}\right)$ was detected in dark walnut samples packaged under air and stored at $20^{\circ} \mathrm{C}$ for 4 months. Crowe et al ${ }^{55)}$ conducted a study with non-oxidized and oxidized (stored at $60^{\circ} \mathrm{C}$ for 8 d) walnut pieces. They determined peroxide values of 0.06 1.58 and 5.02-12.37 meq $\mathrm{O}_{2} \mathrm{~kg}^{-1}$ in non-oxidized and oxidized samples, respectively. Zajdenwerg et $a l .{ }^{56)}$ reported that consumers rejected the nut samples with a peroxide value above 18.8 meq $\mathrm{O}_{2} \mathrm{~kg}^{-1}$ due to their rancid flavor. According to our results, the peroxide values of both light and dark samples -even stored for 6 months- were below 1.5 meq $\mathrm{O}_{2} \mathrm{~kg}^{-1}$. Therefore, it can be concluded that all the samples in the present study are acceptable in terms of peroxide value.

\subsection{Conjugated diene and triene values of ground light and dark walnuts}

The conjugated diene and triene values represent the concentration of conjugated hydroperoxides in oils formed by the shifting of double bonds during oxidation of the unsaturated fatty $\operatorname{acids}^{57)}$. When polyunsaturated fatty acids with three or more double bonds oxidize, conjugation may take place, and this can cause the formation of conjugated trienes. Peroxides that are formed at the beginning of oxidation are quite unstable and can undergo further changes 
a

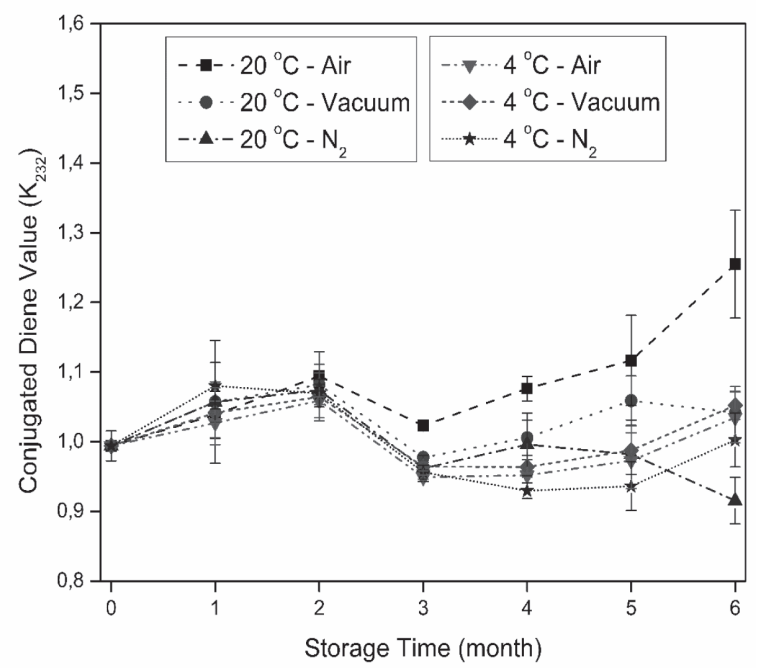

b

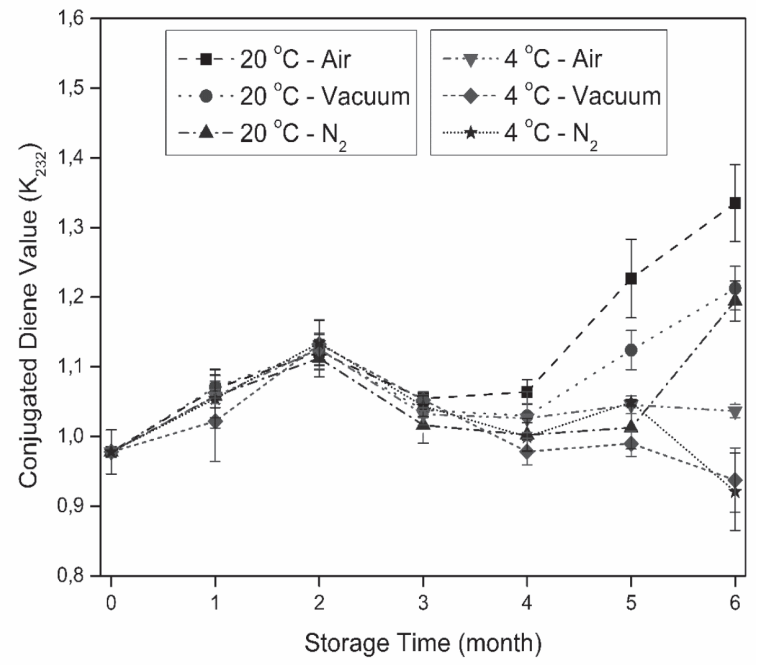

Fig. 4 Conjugated diene values of ground walnuts packaged with different techniques during storage at 4 and $20^{\circ} \mathrm{C}$ (a: light walnuts, b: dark walnuts). The values are the averages $( \pm$ standard deviations) of the results of four independent samples.

resulting in the formation of secondary oxidation products $^{58}$. Conjugated diene values of light and dark walnuts packaged with different techniques and stored for 6 months at 4 and $20^{\circ} \mathrm{C}$ are shown in Figs. $4 \mathrm{a}$ and $4 \mathrm{~b}$, respectively. The initial conjugated diene values of ground light and dark walnuts were $0.99 \pm 0.02$ and $0.98 \pm 0.03$, respectively. These values increased for a while in all samples and then nonsystematically changed during storage at both temperatures. However, a sharp increase was observed in conjugated diene values of the samples packaged under air and stored at $20^{\circ} \mathrm{C}$ after the third month of storage. It should be noted that the highest conjugated diene values for both light and dark walnuts (1.25 and 1.34, respective- a

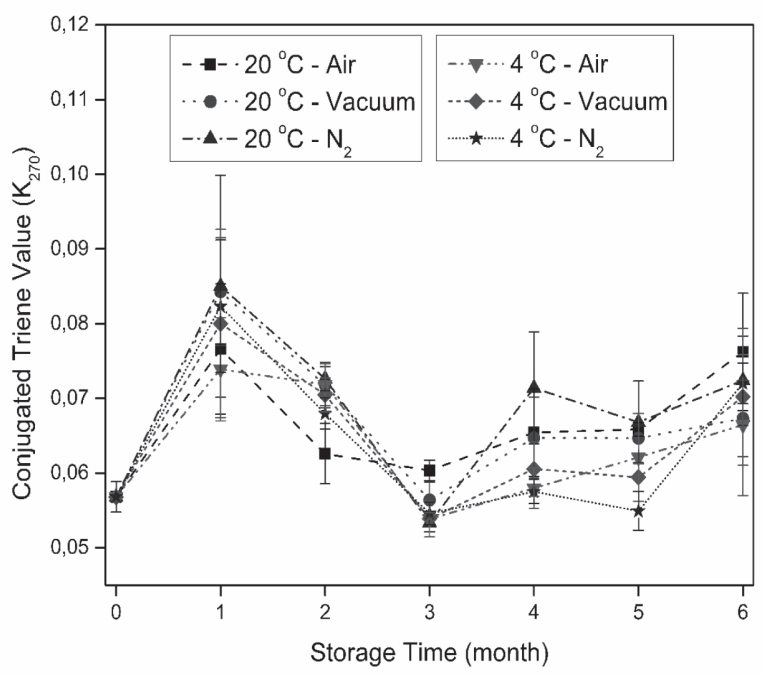

b

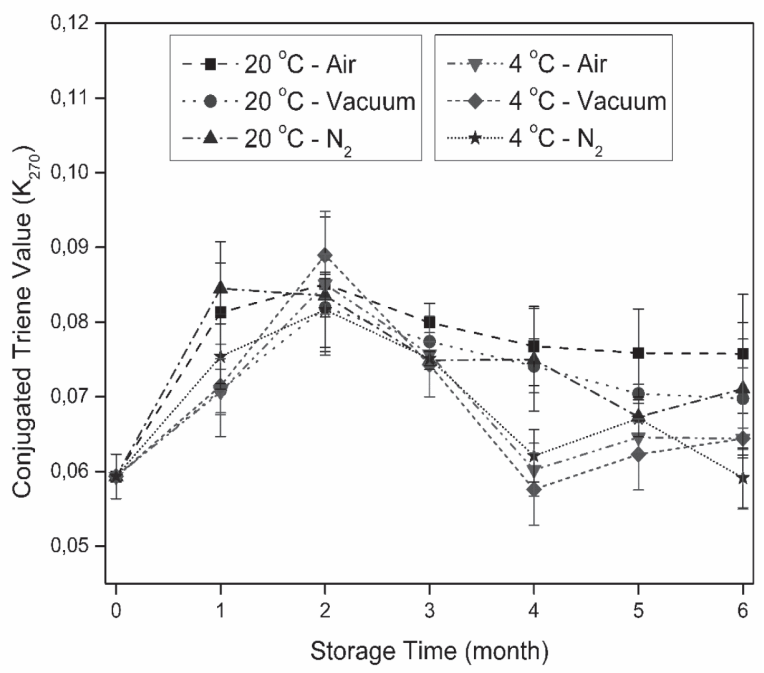

Fig. 5 Conjugated triene values of ground walnuts packaged with different techniques during storage at 4 and $20^{\circ} \mathrm{C}$ (a: light walnuts, b: dark walnuts). The values are the averages $( \pm$ standard deviations) of the results of four independent samples.

ly) were determined in the samples packaged under air and stored at $20^{\circ} \mathrm{C}$. Then, it can be inferred that inappropriate conditions such as oxygen abundance and non-refrigerated storage temperatures result in higher conjugated diene values. This finding is consistent with the studies conducted by the other researchers in the past. Labuckas et al. ${ }^{59)}$ stored partially defatted walnut flour (containing $27 \%$ of total oil) at $25^{\circ} \mathrm{C}$ in plastic laminated packages for 8 months and kept some samples at $-18^{\circ} \mathrm{C}$ as control. At the end of storage, conjugated diene values of the samples stored at $25^{\circ} \mathrm{C}$ were higher than the control samples. The conjugated diene values of walnut oil samples were reported to increase from 1.04 to 3.66 when stored at $25^{\circ} \mathrm{C}$ for 4 


\section{A. Y. Ylldız and H. Karaca}

Table 2 Total phenolic contents of ground light and dark walnuts packaged under air, nitrogen and vacuumpackaged, and stored for 6 months at 4 and $20^{\circ} \mathrm{C}$., b,c

\begin{tabular}{|c|c|c|c|c|c|c|c|c|c|}
\hline \multirow{2}{*}{ Walnut color } & \multirow{2}{*}{$\begin{array}{c}\text { Storage } \\
\text { temperature }\end{array}$} & \multirow{2}{*}{$\begin{array}{c}\text { Packaged } \\
\text { under }\end{array}$} & \multicolumn{7}{|c|}{ Storage Time } \\
\hline & & & Initial & Month 1 & Month 2 & Month 3 & Month 4 & Month 5 & Month 6 \\
\hline \multirow{12}{*}{ LIGHT } & \multirow{6}{*}{$20^{\circ} \mathrm{C}$} & \multirow{2}{*}{ Air } & $22.52 \pm 1.02$ & $27.98 \pm 1.29$ & $20.69 \pm 3.14$ & $19.56 \pm 1.05$ & $18.02 \pm 0.64$ & $13.75 \pm 7.44$ & $14.13 \pm 0.82$ \\
\hline & & & $\mathrm{Aa}$ & $\mathrm{Aa}$ & $\mathrm{Aa}$ & $\mathrm{Aa}$ & Aba & $\mathrm{Ba}$ & $\mathrm{Aa}$ \\
\hline & & \multirow{2}{*}{ Vacuum } & $22.52 \pm 1.02$ & $19.46 \pm 1.04$ & $12.95 \pm 0.69$ & $17.72 \pm 0.91$ & $13.72 \pm 0.68$ & $15.47 \pm 3.56$ & $17.42 \pm 1.54$ \\
\hline & & & $\mathrm{Aa}$ & $\mathrm{Ba}$ & $\mathrm{Ba}$ & $\mathrm{Aa}$ & $\mathrm{Ba}$ & Aba & $\mathrm{Aa}$ \\
\hline & & \multirow{2}{*}{$\mathrm{N}_{2}$} & $22.52 \pm 1.02$ & $28.37 \pm 7.88$ & $19.94 \pm 0.52$ & $19.18 \pm 1.19$ & $22.07 \pm 2.56$ & $18.28 \pm 1.60$ & $16.09 \pm 2.15$ \\
\hline & & & $\mathrm{Aa}$ & $\mathrm{Aa}$ & $\mathrm{Aa}$ & $\mathrm{Aa}$ & $\mathrm{Aa}$ & $\mathrm{Aa}$ & $\mathrm{Aa}$ \\
\hline & \multirow{6}{*}{$4^{\circ} \mathrm{C}$} & \multirow{2}{*}{ Air } & $22.52 \pm 1.02$ & $24.25 \pm 2.37$ & $15.16 \pm 1.74$ & $13.96 \pm 0.46$ & $21.03 \pm 3.55$ & $15.37 \pm 1.97$ & $18.80 \pm 2.35$ \\
\hline & & & $\mathrm{Aa}$ & $\mathrm{Aa}$ & $\mathrm{Aa}$ & $\mathrm{Aa}$ & $\mathrm{Aa}$ & $\mathrm{Ba}$ & $\mathrm{Aa}$ \\
\hline & & \multirow{2}{*}{ Vacuum } & $22.52 \pm 1.02$ & $22.82 \pm 3.64$ & $13.71 \pm 6.34$ & $15.21 \pm 3.82$ & $17.10 \pm 3.11$ & $13.53 \pm 1.47$ & $18.12 \pm 5.70$ \\
\hline & & & $\mathrm{Aa}$ & $\mathrm{Aa}$ & $\mathrm{Aa}$ & $\mathrm{Aa}$ & $\mathrm{Aa}$ & $\mathrm{Ba}$ & $\mathrm{Aa}$ \\
\hline & & \multirow{2}{*}{$\mathrm{N}_{2}$} & $22.52 \pm 1.02$ & $24.83 \pm 6.93$ & $16.50 \pm 1.68$ & $17.74 \pm 4.64$ & $19.82 \pm 2.20$ & $21.46 \pm 1.44$ & $20.13 \pm 1.60$ \\
\hline & & & $\mathrm{Aa}$ & $\mathrm{Aa}$ & $\mathrm{Aa}$ & $\mathrm{Aa}$ & $\mathrm{Aa}$ & $\mathrm{Aa}$ & $\mathrm{Aa}$ \\
\hline \multirow{12}{*}{ DARK } & \multirow{6}{*}{$20^{\circ} \mathrm{C}$} & \multirow{2}{*}{ Air } & $18.32 \pm 1.06$ & $11.03 \pm 4.35$ & $11.75 \pm 2.58$ & $11.21 \pm 1.41$ & $11.31 \pm 0.85$ & $11.43 \pm 2.49$ & $9.01 \pm 2.62$ \\
\hline & & & $\mathrm{Aa}$ & $\mathrm{Ab}$ & $\mathrm{Ab}$ & $\mathrm{Ab}$ & $\mathrm{Ab}$ & $\mathrm{Aa}$ & $\mathrm{Ab}$ \\
\hline & & \multirow{2}{*}{ Vacuum } & $18.32 \pm 1.06$ & $13.24 \pm 1.20$ & $8.85 \pm 2.07$ & $10.15 \pm 2.59$ & $9.16 \pm 0.56$ & $11.40 \pm 2.44$ & $10.98 \pm 0.19$ \\
\hline & & & $\mathrm{Aa}$ & $\mathrm{Ab}$ & $\mathrm{Ab}$ & $\mathrm{Ab}$ & $\mathrm{Ab}$ & $\mathrm{Aa}$ & $\mathrm{Ab}$ \\
\hline & & \multirow{2}{*}{$\mathrm{N}_{2}$} & $18.32 \pm 1.06$ & $15.08 \pm 3.95$ & $8.51 \pm 1.65$ & $11.34 \pm 2.20$ & $9.63 \pm 1.66$ & $13.04 \pm 0.66$ & $11.34 \pm 1.12$ \\
\hline & & & $\mathrm{Aa}$ & $\mathrm{Ab}$ & $\mathrm{Ab}$ & $\mathrm{Ab}$ & $\mathrm{Ab}$ & $\mathrm{Ab}$ & $\mathrm{Ab}$ \\
\hline & \multirow{6}{*}{$4^{\circ} \mathrm{C}$} & \multirow{2}{*}{ Air } & $18.32 \pm 1.06$ & $14.86 \pm 2.97$ & $7.73 \pm 2.20$ & $9.76 \pm 0.95$ & $14.79 \pm 1.38$ & $12.01 \pm 2.53$ & $15.05 \pm 5.06$ \\
\hline & & & $\mathrm{Aa}$ & $\mathrm{ABb}$ & $\mathrm{Ab}$ & $\mathrm{Aa}$ & $\mathrm{Ab}$ & $\mathrm{Aa}$ & $\mathrm{Aa}$ \\
\hline & & \multirow{2}{*}{ Vacuum } & $18.32 \pm 1.06$ & $12.89 \pm 0.88$ & $7.52 \pm 1.81$ & $8.41 \pm 0.95$ & $12.31 \pm 1.95$ & $7.68 \pm 0.46$ & $9.52 \pm 1.22$ \\
\hline & & & $\mathrm{Aa}$ & $\mathrm{Bb}$ & $\mathrm{Ab}$ & $\mathrm{Ab}$ & $\mathrm{Ab}$ & $\mathrm{Ab}$ & $\mathrm{Bb}$ \\
\hline & & \multirow{2}{*}{$\mathrm{N}_{2}$} & $18.32 \pm 1.06$ & $18.77 \pm 1.52$ & $8.29 \pm 1.90$ & $11.00 \pm 1.74$ & $12.52 \pm 1.71$ & $10.32 \pm 1.43$ & $11.69 \pm 0.61$ \\
\hline & & & $\mathrm{Aa}$ & $\mathrm{Ab}$ & $\mathrm{Ab}$ & $\mathrm{Ab}$ & $\mathrm{Ab}$ & $\mathrm{Ab}$ & $\mathrm{ABb}$ \\
\hline
\end{tabular}

${ }^{a}$ The values are the averages ( \pm standard deviations) of the results of four independent samples.

${ }^{\mathrm{b}}$ Different letters shown with uppercase indicate significant differences among different packaging techniques $(p<0.05)$.

${ }^{\mathrm{c}}$ Different letters shown with lowercase indicate significant differences between light and dark walnuts $(p<0.05)$.

months ${ }^{60)}$ and from 0.5 to 29.99 at $60^{\circ} \mathrm{C}$ in only 12 days $^{611}$. The conjugated diene values of the walnut samples (both light and dark) in the present study were far below these values even at the end of 6 -month storage. It might be due to the fact that our samples were ground walnut samples (ground kernels with their pellicles) during storage in contrast to the studies conducted with walnut oil. It is wellknown that phenolics and other antioxidants are accumulated in the pellicle and these compounds may slow down the oxidation processes and limit the increase of conjugated diene values.

Conjugated triene values of light and dark walnuts packaged with different techniques and stored for 6 months at 4 and $20^{\circ} \mathrm{C}$ are shown in Figs. $5 \mathrm{a}$ and $5 \mathrm{~b}$, respectively. Conjugated triene values of both light and dark walnut samples were determined as 0.06 at the beginning of the storage. These values did not vary significantly along storage period and increased to a maximum of 0.09 for both light and dark samples. It might be due to the limited formation of secondary oxidation products during storage of walnuts. Such low results were reported by Martínez et $a l .{ }^{62)}$ who investigated the effect of natural and synthetic antioxidants on the oxidation stability of walnut oil during storage for 6 months at $25^{\circ} \mathrm{C}$. They determined conjugated triene values of $0.08-0.09$ and $0.06-0.17$ in the presence and absence of antioxidant additives, respectively. Raisi et $a l .{ }^{51)}$ conducted an experiment with unpackaged almonds and reported conjugated triene values of $0.35-1.13$ and 0.35-2.02 for the ground samples stored for 6 months at 4 and $23^{\circ} \mathrm{C}$, respectively.

\subsection{Total phenolic contents of ground light and dark wal- nuts}

Phenolic compounds are secondary metabolites commonly found in plants that protect them against abiotic and biotic stress conditions. Phenolic substances in the walnut are mostly found in the pellicle surrounding the kernel. Total phenolic contents of light and dark walnuts packaged with different techniques and stored for 6 months at 4 and $20^{\circ} \mathrm{C}$ are shown in Table 2. As can be seen from the table, 


\section{Oil Quality of Light and Dark Walnuts}

Table 3 Antioxidant activities of ground light and dark walnuts packaged under air, nitrogen and vacuumpackaged, and stored for 6 months at 4 and $20^{\circ} \mathrm{C}$., b, c

\begin{tabular}{|c|c|c|c|c|c|c|c|c|c|}
\hline \multirow{2}{*}{ Walnut color } & \multirow{2}{*}{$\begin{array}{c}\text { Storage } \\
\text { temperature }\end{array}$} & \multirow{2}{*}{$\begin{array}{c}\text { Packaged } \\
\text { under }\end{array}$} & \multicolumn{7}{|c|}{ Storage Time } \\
\hline & & & Initial & Month 1 & Month 2 & Month 3 & Month 4 & Month 5 & Month 6 \\
\hline \multirow{12}{*}{ LIGHT } & \multirow{6}{*}{$20^{\circ} \mathrm{C}$} & \multirow{2}{*}{ Air } & $24.27 \pm 4.57$ & $25.30 \pm 1.92$ & $24.94 \pm 2.74$ & $22.42 \pm 4.56$ & $19.62 \pm 3.74$ & $25.10 \pm 3.48$ & $23.59 \pm 1.81$ \\
\hline & & & $\mathrm{Aa}$ & $\mathrm{Aa}$ & $\mathrm{Aa}$ & $\mathrm{Aa}$ & $\mathrm{Aa}$ & $\mathrm{Aa}$ & $\mathrm{Aa}$ \\
\hline & & \multirow{2}{*}{ Vacuum } & $24.27 \pm 4.57$ & $11.15 \pm 3.71$ & $16.86 \pm 3.79$ & $20.45 \pm 1.22$ & $9.94 \pm 2.29$ & $24.36 \pm 3.83$ & $22.53 \pm 0.77$ \\
\hline & & & $\mathrm{Aa}$ & $\mathrm{Ba}$ & $\mathrm{Ba}$ & $\mathrm{Aa}$ & $\mathrm{Ba}$ & $\mathrm{Aa}$ & $\mathrm{Aa}$ \\
\hline & & \multirow{2}{*}{$\mathrm{N}_{2}$} & $24.27 \pm 4.57$ & $25.23 \pm 6.82$ & $24.13 \pm 1.76$ & $20.06 \pm 0.74$ & $23.23 \pm 3.22$ & $21.43 \pm 5.70$ & $21.35 \pm 5.43$ \\
\hline & & & $\mathrm{Aa}$ & $\mathrm{Aa}$ & $\mathrm{Aa}$ & $\mathrm{Aa}$ & $\mathrm{Aa}$ & $\mathrm{Aa}$ & $\mathrm{Aa}$ \\
\hline & \multirow{6}{*}{$4^{\circ} \mathrm{C}$} & \multirow{2}{*}{ Air } & $24.27 \pm 4.57$ & $17.22 \pm 1.78$ & $21.51 \pm 4.13$ & $14.52 \pm 1.68$ & $21.22 \pm 3.65$ & $17.85 \pm 1.34$ & $17.84 \pm 1.79$ \\
\hline & & & $\mathrm{Aa}$ & $\mathrm{Aa}$ & $\mathrm{Aa}$ & $\mathrm{Ba}$ & $\mathrm{Aa}$ & $\mathrm{Ba}$ & $\mathrm{Ba}$ \\
\hline & & \multirow{2}{*}{ Vacuum } & $24.27 \pm 4.57$ & $9.91 \pm 1.51$ & $14.41 \pm 3.13$ & $18.99 \pm 6.71$ & $18.58 \pm 1.48$ & $14.76 \pm 3.81$ & $19.43 \pm 5.02$ \\
\hline & & & Aa & $\mathrm{Ba}$ & $\mathrm{Ba}$ & $\mathrm{ABa}$ & Aa & $\mathrm{Ba}$ & Aba \\
\hline & & \multirow{2}{*}{$\mathrm{N}_{2}$} & $24.27 \pm 4.57$ & $20.22 \pm 5.36$ & $19.13 \pm 2.28$ & $20.63 \pm 0.87$ & $19.85 \pm 3.06$ & $25.68 \pm 0.94$ & $23.27 \pm 1.17$ \\
\hline & & & $\mathrm{Aa}$ & $\mathrm{Aa}$ & $\mathrm{Aa}$ & $\mathrm{Aa}$ & $\mathrm{Aa}$ & $\mathrm{Aa}$ & $\mathrm{Aa}$ \\
\hline \multirow{12}{*}{ DARK } & \multirow{6}{*}{$20^{\circ} \mathrm{C}$} & \multirow{2}{*}{ Air } & $9.38 \pm 0.09$ & $3.50 \pm 1.63$ & $9.27 \pm 0.64$ & $7.99 \pm 0.81$ & $7.26 \pm 0.92$ & $8.59 \pm 1.56$ & $4.38 \pm 1.42$ \\
\hline & & & $\mathrm{Ab}$ & $\mathrm{Bb}$ & $\mathrm{Ab}$ & $\mathrm{Ab}$ & $\mathrm{Ab}$ & $\mathrm{Ab}$ & $\mathrm{Ab}$ \\
\hline & & \multirow{2}{*}{ Vacuum } & $9.38 \pm 0.09$ & $7.64 \pm 0.18$ & $6.47 \pm 1.32$ & $6.90 \pm 2.23$ & $5.92 \pm 0.66$ & $9.05 \pm 0.67$ & $5.05 \pm 0.40$ \\
\hline & & & $\mathrm{Ab}$ & Aba & $\mathrm{Ab}$ & $\mathrm{Ab}$ & $\mathrm{Aa}$ & $\mathrm{Ab}$ & $\mathrm{Ab}$ \\
\hline & & \multirow{2}{*}{$\mathrm{N}_{2}$} & $9.38 \pm 0.09$ & $8.00 \pm 1.61$ & $6.91 \pm 0.31$ & $8.19 \pm 1.87$ & $6.48 \pm 1.37$ & $9.27 \pm 1.71$ & $5.58 \pm 0.61$ \\
\hline & & & $\mathrm{Ab}$ & $\mathrm{Ab}$ & $\mathrm{Ab}$ & $\mathrm{Ab}$ & $\mathrm{Ab}$ & $\mathrm{Ab}$ & $\mathrm{Ab}$ \\
\hline & \multirow{6}{*}{$4^{\circ} \mathrm{C}$} & \multirow{2}{*}{ Air } & $9.38 \pm 0.09$ & $8.01 \pm 0.38$ & $5.17 \pm 0.98$ & $6.38 \pm 0.95$ & $10.24 \pm 0.53$ & $8.28 \pm 2.51$ & $5.54 \pm 0.79$ \\
\hline & & & $\mathrm{Ab}$ & $\mathrm{Ab}$ & $\mathrm{Ab}$ & $\mathrm{Ab}$ & $\mathrm{Ab}$ & $\mathrm{Ab}$ & $\mathrm{Ab}$ \\
\hline & & \multirow{2}{*}{ Vacuum } & $9.38 \pm 0.09$ & $6.22 \pm 1.85$ & $5.75 \pm 0.76$ & $5.73 \pm 1.31$ & $8.18 \pm 0.88$ & $4.49 \pm 0.97$ & $4.66 \pm 0.97$ \\
\hline & & & $\mathrm{Ab}$ & $\mathrm{Aa}$ & $\mathrm{Ab}$ & $\mathrm{Ab}$ & $\mathrm{Ab}$ & $\mathrm{Ab}$ & $\mathrm{Ab}$ \\
\hline & & \multirow{2}{*}{$\mathrm{N}_{2}$} & $9.38 \pm 0.09$ & $9.26 \pm 0.20$ & $6.40 \pm 1.80$ & $7.82 \pm 1.07$ & $9.37 \pm 1.11$ & $7.10 \pm 1.60$ & $7.01 \pm 0.38$ \\
\hline & & & $\mathrm{Ab}$ & $\mathrm{Ab}$ & $\mathrm{Ab}$ & $\mathrm{Ab}$ & $\mathrm{Ab}$ & $\mathrm{Ab}$ & $\mathrm{Ab}$ \\
\hline
\end{tabular}

${ }^{a}$ The values are the averages ( \pm standard deviations) of the results of four independent samples.

${ }^{\mathrm{b}}$ Different letters shown with uppercase indicate significant differences among different packaging techniques $(p<0.05)$.

${ }^{\mathrm{c}}$ Different letters shown with lowercase indicate significant differences between light and dark walnuts $(p<0.05)$.

total phenolic content of dark walnuts was lower than that of light ones at the beginning of storage. Similarly, Fuentealba et $a l .{ }^{15)}$ reported that total phenolic content was significantly higher in light walnut kernels than in amber kernels. This may be due to the decrease in the phenolic content in the pellicle covering the surface of the kernel as a result of enzymatic browning reactions. The phenolic compounds, which are the substrates of enzymatic browning, oxidize to quinones and then brown substances are formed as a result of the polymerization reactions of quinones ${ }^{63)}$. In general, total phenolic contents of all samples decreased during storage. According to our results, refrigerated storage conditions has a protective effect on phenolics of light walnuts; but on the other hand, vacuum-packaging or packaging under nitrogen did not limit the decrease in the total phenolic content of the walnuts at $20^{\circ} \mathrm{C}$ with only one exception (vacuum-packaged light walnuts). Previous studies reported that factors such as packaging technique ${ }^{64)}$ and storage temperature ${ }^{65}$ did not have a definite effect on total phenolic contents of the nuts.

The protective role of phenolic compounds against oxidation reactions is well-known ${ }^{66)}$. Our results showed that the total phenolic contents of dark walnuts were lower than that of light ones at the beginning and during the whole storage period. Then, it can be expected that dark walnuts are more susceptible to oxidation reactions. However, our findings related with lipid oxidation (peroxide, conjugated diene and triene values) showed that lipid oxidation occurred in the dark walnuts were not higher than that occurred in the light ones. As a results, it can be concluded that walnut phenolics even at relatively low amounts were effective in protecting from oxidation.

\subsection{Antioxidant activities of ground light and dark walnuts}

Antioxidants are the substances which have the ability to prevent/delay the onset and/or propagation of oxidation reactions. There are many phytochemicals with antioxidant activity in walnut fruit some of which located in defatted kernel while some others are dissolved in its oil. Arranz et 


\section{A. Y. Ylldız and H. Karaca}

$a l .{ }^{67)}$ reported that the defatted part of the walnut kernel provides the bulk of the antioxidant capacity of the fruit and the contribution of its oil to the overall antioxidant capacity is less than $5 \%$. Antioxidant activity of light and dark walnuts packaged with different techniques and stored for 6 months at 4 and $20^{\circ} \mathrm{C}$ are shown in Table 3. At the beginning of the storage, the antioxidant activity of dark walnuts were about 2.5-fold lower than that of light ones. It is probably due to the fact that phenolics in the dark walnuts were already oxidized before storage. However, it should be noted that there were no significant differences between lipid oxidation parameters (peroxide, conjugated diene and triene) of light and dark walnuts according to our results. Then, in our opinion, the oxygen in the environment first meets the pellicle and the antioxidants in the pellicle(i.e. phenolics)react with the oxygen and prevent the reaction of oxygen with the oil of the fruit. As long as the antioxidants in the pellicle are oxidized, walnut color darkens but oil is protected from oxidation.

Antioxidant activity of dark walnuts did not change significantly during the storage at both temperatures. In case of light walnuts, even though some drastic decreases (up to $40 \%$ ) were observed in the antioxidant activity values, this situation was not consistent throughout the storage periods. Similarly, fluctuations in the antioxidant activities during storage of some other nuts were reported ${ }^{64,68)}$. The authors explained this phenomenon by many complex oxidation mechanisms and complicated biochemical reactions. Phenolic substances can easily undergo oxidation reactions and turn into brown colored polymers. However, prior to the formation of these brown polymers, phenolics are partially oxidized and converted to uncolored intermediate products. These intermediate products were reported to have higher antioxidant activity than the original phenolics and the brown polymers ${ }^{69,70)}$. Boiling et al. ${ }^{65)}$ stored almonds at 4 and $20^{\circ} \mathrm{C}$ for 15 months and periodically analyzed total phenolic content and antioxidant activity. Contrary to their hypothesis that storage would decrease the antioxidant activity, almonds stored at both temperatures had increased phenolic content and antioxidant activity values. This result was attributed to increased extractability and/or continuing synthesis of polyphenols during storage of almonds. The authors also stated that the storage temperature of almonds did not affect phenolic content and antioxidant activity. Likewise, storage temperature and packaging techniques tested in the present study did not have any significant effect on antioxidant activity of the walnuts.

\subsection{Tocopherols contents of ground light and dark wal- nuts}

Tocopherols are important antioxidants which are abundantly found in nuts and vegetable oils. They compete with unsaturated fatty acids for lipid peroxy radicals and hence a

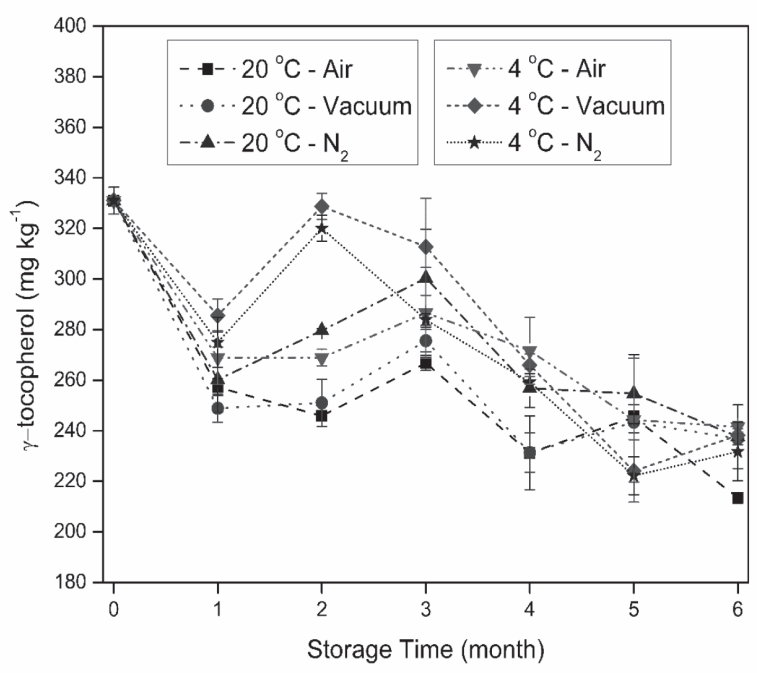

b

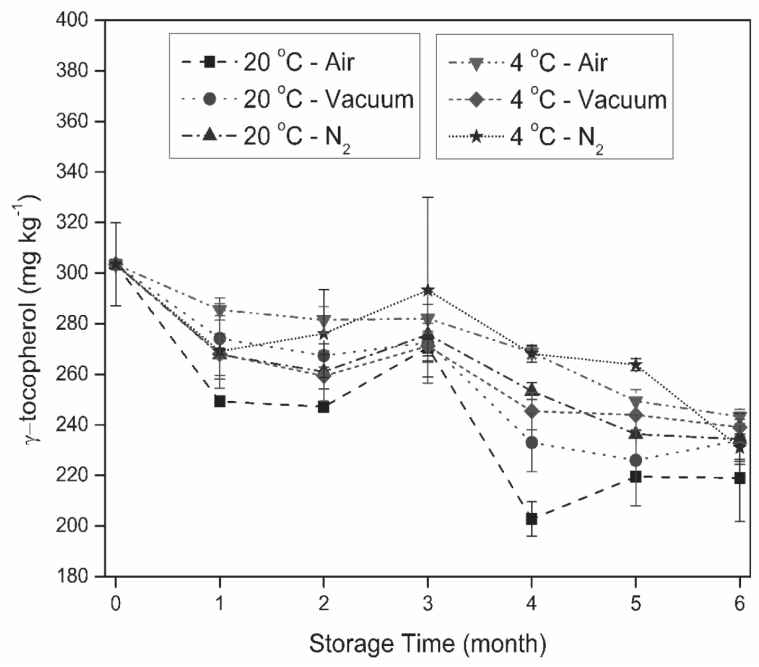

Fig. $6 \gamma$-tocopherol contents of ground walnuts packaged with different techniques during storage at 4 and $20^{\circ} \mathrm{C}$ (a: light walnuts, b: dark walnuts). The values are the averages $( \pm$ standard deviations) of the results of four independent samples.

improve oxidative stability ${ }^{71}$. It has been reported that, of four isomers of tocopherols $(\alpha-, \beta-, \gamma$-, and $\delta$ - $), \gamma$-tocopherol is the most abundant form whereas $\beta$-tocopherol is rarely present in walnut oil ${ }^{72,73)}$. Likewise, the concentrations of tocopherols ranked as follows: $\gamma$-, $\delta$ - and $\alpha$-tocopherols, while $\beta$-tocopherol was not detected in our samples. $\gamma$-, $\delta$ and $\alpha$-tocopherol contents of walnut samples packaged with different techniques and stored for 6 months at two different temperatures are shown in Figs. 6, 7 and 8, respectively. At the beginning of storage, $\gamma_{-}, \delta$ - and $\alpha$-tocopherol concentrations were $331.0 \pm 5.3,53.4 \pm 4.55$ and $13.6 \pm 1.6 \mathrm{mg} \mathrm{kg}^{-1}$ in light walnuts and $303.5 \pm 16.3$, $51.0 \pm 5$ and $11.8 \pm 0.55 \mathrm{mg} \mathrm{kg}^{-1}$ in dark walnuts, respectively. These differences between tocopherol contents of 
a

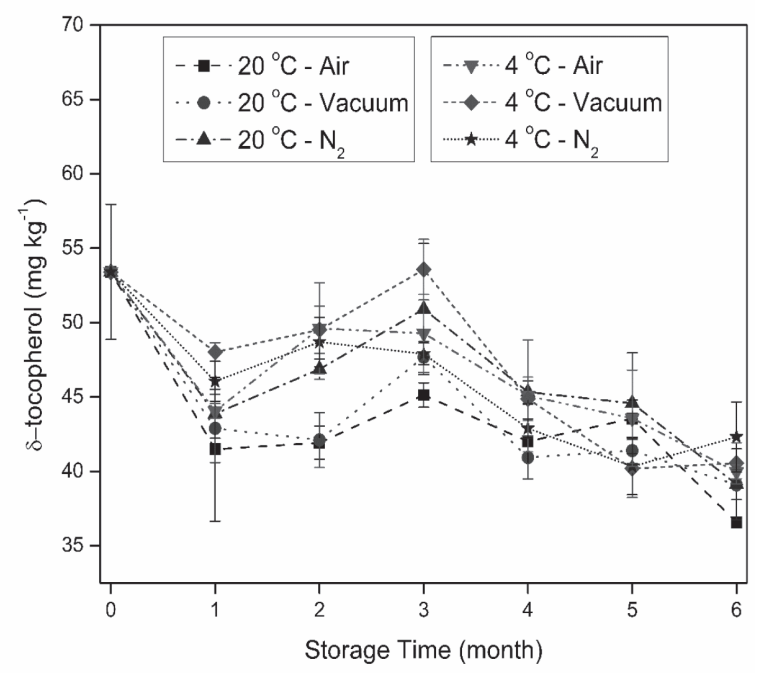

b

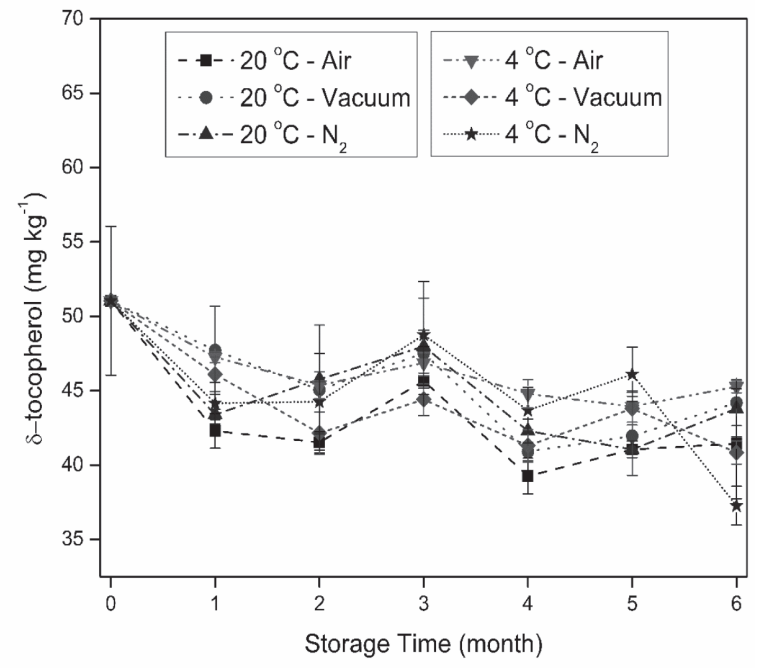

Fig. $7 \quad \delta$-tocopherol contents of ground walnuts packaged with different techniques during storage at 4 and $20^{\circ} \mathrm{C}$ (a: light walnuts, b: dark walnuts). The values are the averages $( \pm$ standard deviations) of the results of four independent samples.

light and dark walnuts were slight but significant $(p<0.05)$ according to the statistical analysis. It could be attributed to the presence of more antioxidant substances on the surface of light walnuts -compared to dark ones- limiting the oxidation of the tocopherols inside the kernel. Tocopherols are dissolved in the oil of the walnut and the oil is dispersed in the kernel as droplets surrounded by a single layer of phospholipids embedded with proteins termed oleoresins ${ }^{74)}$. This structure provides a protection of the components in the oil from oxidation. However, it should be noted that, this protection effect is unique to the intact form of the kernel and disappears when the integrity is disrupted by a process like grinding just as in the present study. We determined that there were no significant differ- a

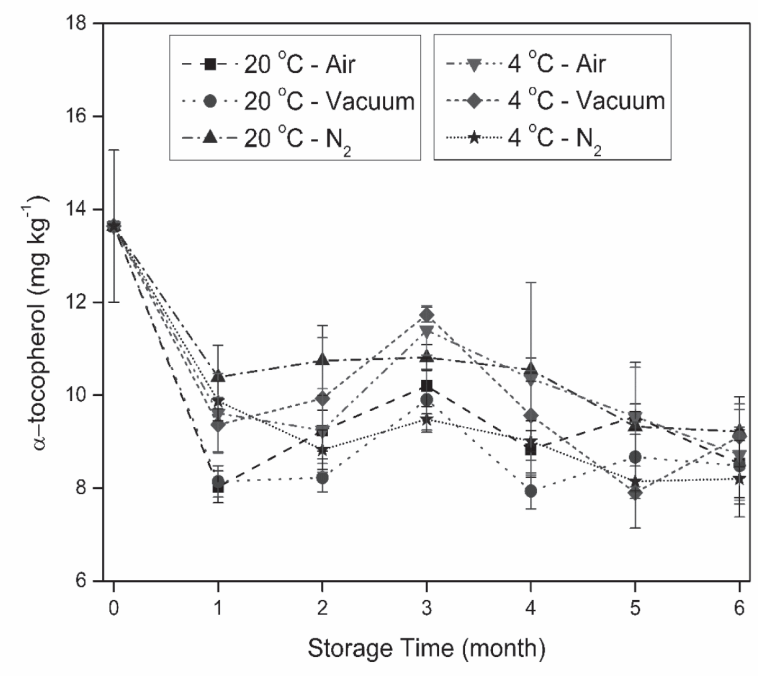

b

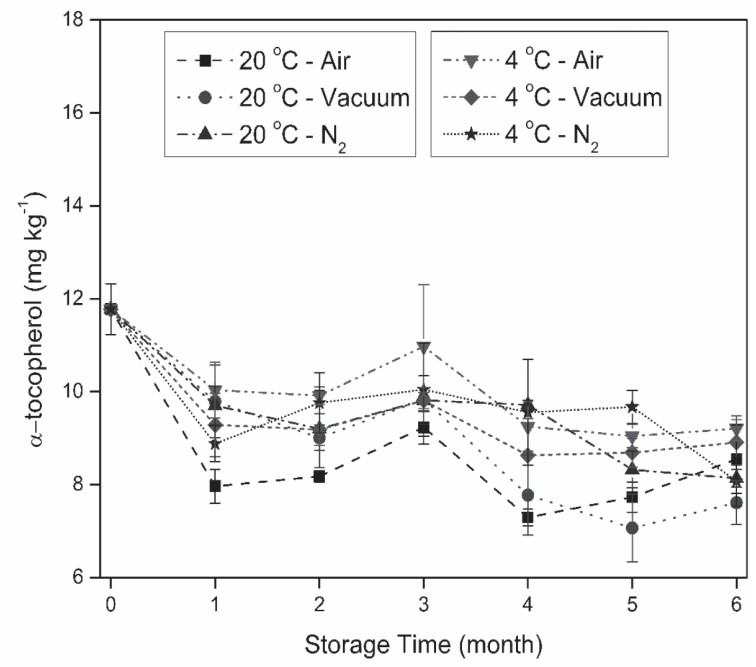

Fig. $8 \alpha$-tocopherol contents of ground walnuts packaged with different techniques during storage at 4 and $20^{\circ} \mathrm{C}$ (a: light walnuts, b: dark walnuts). The values are the averages ( \pm standard deviations) of the results of four independent samples.

ences between the concentrations of any tocopherol types in light and dark walnuts at the end of 6-month storage of ground samples (Figs. 6-8). Probably, tocopherols in the oil leaked from the cells as a result of grinding process were oxidized in time. It was reported that the relative antioxidant activity of the tocopherols is in the order of $\alpha->\gamma->$ $\delta$-tocopherol ${ }^{75,76)}$. According to our calculations, decreases in $\alpha$-, $\gamma$ - and $\delta$-tocopherol levels were $26.6-39.9 \%, 27.0$ $35.5 \%$ and $20.8-31.5 \%$ in light walnuts and $21.8-35.4 \%$, $19.8-27.8 \%$ and $11.3-27.0 \%$ in dark walnuts, respectively, at the end of storage for 6 months. Then, it can be concluded that the more antioxidant activity the tocopherol has, the more pronounced decrease occurs.

Statistical analysis revealed that there were no signifi- 


\section{A. Y. Ylldiz and H. Karaca}

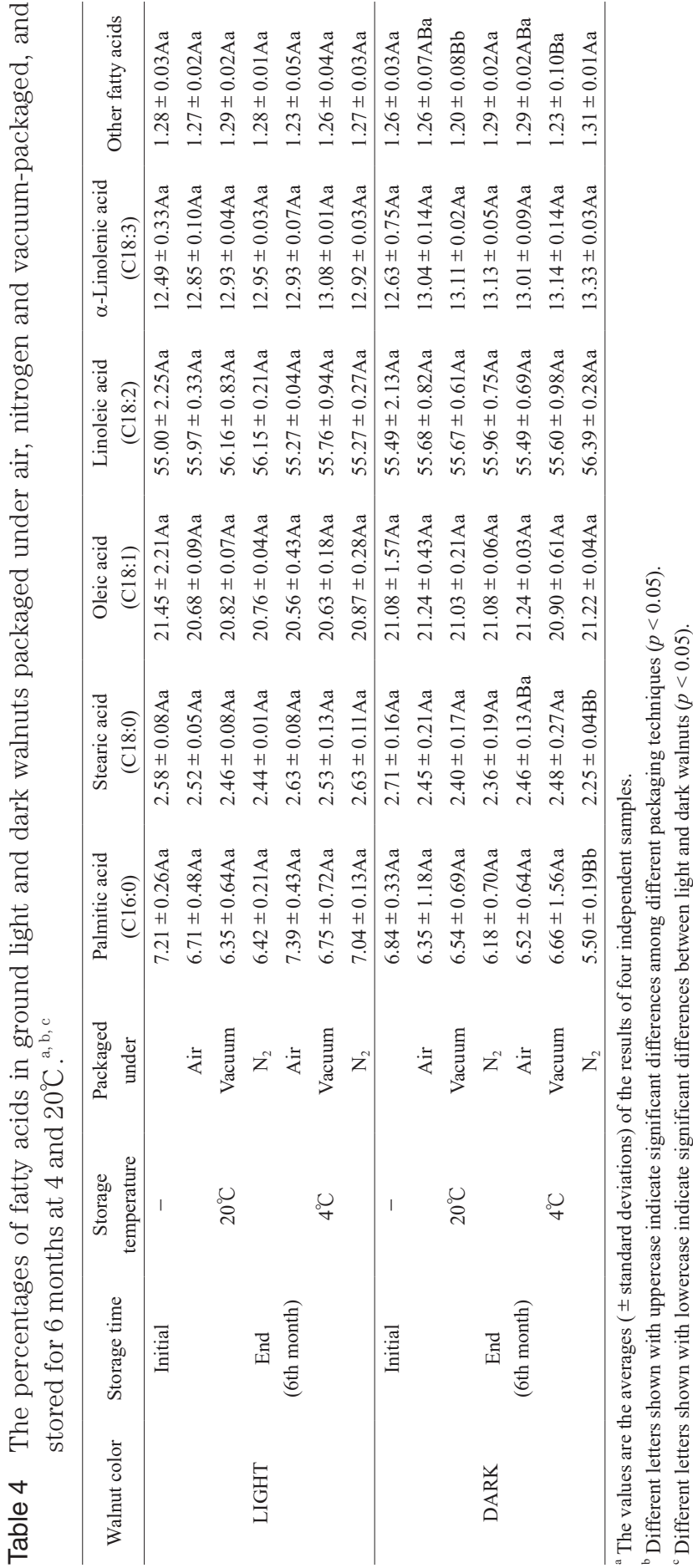

cant differences among the tocopherol contents of the walnut samples packaged with different techniques and stored at different temperatures $(p>0.05)$. Similarly, García-Pascual et $a l .{ }^{52)}$ reported that neither storage temperature nor packaging atmosphere had a significant effect on $\alpha$-tocopherol content of almonds packaged under nitrogen and air and stored at 8 and $36^{\circ} \mathrm{C}$. In our opinion, not only atmospheric oxygen but also other factors such as free radicals formed during oxidation chain reactions have an important role on the levels of tocopherols.

\subsection{Fatty acid compositions of ground light and dark wal- nuts}

Fatty acid composition is an indicator of the ratios of saturated, mono- and poly-unsaturated fatty acids and can give an idea about the nutritional quality of the oil. Walnut oil is rich in unsaturated fatty acids and is famous for its high linoleic acid content. However, high content of unsaturated fatty acids makes the fruit quite susceptible to oxidation reactions.

In parallel with the previous studies ${ }^{77,78)}$, we found that the approximate ratios of saturated, mono-unsaturated and poly-unsaturated fatty acids in walnut samples were 9, 22 and $68 \%$, respectively, and linoleic acid was the major fatty acid in both light and dark walnut samples. The percentages of linoleic, oleic, linolenic, palmitic and stearic acids in ground light walnut samples were 55.00, 21.45, 12.49, 7.21 and $2.58 \%$, respectively, prior to storage. The corresponding values in ground dark walnuts were 55.49, 21.08, 12.63, 6.84 and $2.71 \%$, respectively. Other fatty acids (myristic, palmitoleic, vaccenic, arachidic and eicocenoic acids)constituted a sum of about $1 \%$. Table 4 gives the percentages of fatty acids in ground light and dark walnut samples at the end of storage for 6 months at 4 and $20^{\circ} \mathrm{C}$. The fatty acid compositions of light and dark walnuts were statistically similar at both the beginning and the end of the storage. Moreover, no significant differences were found among the values of any fatty acids during storage $(p>$ $0.05)$. Although measurement of changes in fatty acid composition is not widely used in assessing lipid oxidation, the changes occurred in this composition was reported to be an indicator of oxidative changes in highly unsaturated vegetable oils ${ }^{79)}$. Therefore, the stability in fatty acid composition of our samples could be attributed to the protective effect of natural antioxidants such as tocopherols, phenolics, etc. found in walnuts.

\section{Conclusion}

In this study, we investigated the effects of packaging techniques and storage temperature on the chemical properties of ground light and dark walnuts. We observed that free fatty acid contents increased during storage and these 
increases were marked for dark walnuts. Peroxide values of all samples fluctuated during storage. Both free fatty acid contents and peroxide values recorded at the end of storage were higher than the initial values. Storage at refrigerated temperature significantly reduced the increases of free fatty acid contents, peroxide and conjugated diene values. Fatty acid composition and triene values did not change significantly at any storage conditions tested in this study. Dark walnuts had lower phenolic and tocopherol contents than the light ones, but even this lower contents of antioxidant compounds were sufficient to protect the fruit against oxidation reactions. According to our results; ground dark walnuts, just as the light ones, can be stored for at least 6 months even in the packages with air. All walnut samples were acceptable at the end of 6-month storage in terms of oxidation parameters. Further research is needed to provide data on the acceptability of the sensory quality attributes of dark walnuts and to relate them with their chemical characteristics.

\section{Authorship Contributions}

Aysun Yurdunuseven Yıldı: Conceptualization, Methodology, Formal analysis, Investigation, Software, Validation, Writing - original draft. Hakan Karaca: Supervision, Conceptualization, Methodology, Investigation, Writing - review \& editing.

\section{Acknowledgements}

This study was supported by Scientific Research Project Foundation of Pamukkale University (Project numbers 2019FEBE002 and 2018HZDP016).

\section{Conflict of Interest}

The authors declare no actual or potential conflict of interest including any financial, personal or other relationships with other people or organizations.

\section{References}

1) FAOSTAT[Internet]. Database on Crops. Food and Agriculture Organization of the United Nations. Rome, Italy. http://www.fao.org/faostat/en/\#data/QC. Accessed 7 October 2021.

2) Pycia, K.; Kapusta, I.; Jaworska, G.; Jankowska, A. Antioxidant properties, profile of polyphenolic compounds and tocopherol content in various walnut (Juglans regia L.) varieties. Eur. Food Res. Technol.
245, 607-616(2019).

3) Ojeda-Amador, R.M.; Salvador, M.D.; Gómez-Alonso, S.; Fregapane, G. Characterization of virgin walnut oils and their residual cakes produced from different varieties. Food Res. Int. 108, 396-404(2018).

4) Colaric, M.; Veberic, R.; Solar, A.; Hudina, M.; Stampar, F. Phenolic acids, syringaldehyde, and juglone in fruits of different cultivars of Juglans regia L. J. Agric. Food Chem. 53, 6390-6396(2005).

5) Ortiz, C.M.; Vicente, A.R.; Fields, R.P.; Grillo, F.; Labavitch, J.M.; Donis-Gonzalez, I.; Crisosto, C.H. Walnut (Juglans regia L.) kernel postharvest deterioration as affected by pellicle integrity, cultivar and oxygen concentration. Postharvest Biol. Technol. 156, 110948 (2019).

6) Brawner, S.A.; Warmund, M.R. Husk softening and kernel characteristics of three black walnut cultivars at successive harvest dates. HortScience 43, 691-695 (2008).

7) Solar, A.; Jakopic, J.; Miklavc, J.; Stampar, F.; Veberic, R.; Trdan, S. Walnut husk fly substantially affects sensory attributes and phenolic contents of the kernels in common walnut. Sci. Hortic. (Amsterdam) 247, 17-26 (2019).

8) Koyuncu, M.A.; Koyuncu, F.; Bakir, N. Selected dryıng conditions and storage period and quality of walnut selections. J. Food Process. Preserv. 27, 87-99 (2003).

9) Zhang, B.; Zheng, A.; Zhou, L.; Huang, Z.; Wang, S. Developing hot air-assisted radio frequency drying protocols for in-shell walnuts. Emirates J. Food Agric. 28, 459-467 (2016).

10) Abbaspour-Gilandeh, Y.; Kaveh, M.; Jahanbakhshi, A. The effect of microwave and convective dryer with ultrasound pre-treatment on drying and quality properties of walnut kernel. J. Food Process. Preserv. 43, e12868 (2019).

11) Hassan-Beygi, S.R.; Aghbashlo, M.; Kianmehr, M.H.; Massah, J. Drying char-acteristics of walnut (Juglans regia L.) during convection drying. Int. Agrophys. 23, 129-135 (2009).

12) Zhang, S.; Tian, L.; Zhang, Y.; Zhao, H.; Zhao, J.; Guo, J.; Zhu, G.P. De novo transcriptome assembly of the fresh-cut white husk of Juglans cathayensis Dode: Insights for enzymatic browning mechanism of freshcut husk of walnut. Sci. Hortic. (Amsterdam) 257, 108654 (2019).

13) UNECE[Internet]. UNECE (United Nations Economic Commission for Europe) standart DDP-02 concerning the marketing and commercial quality control of walnut kernels. United Nations, New York and Geneva. https:/www.unece.org/fileadmin/DAM/trade/agr/standard/dry/Standards/DDP02_Walnutkernels_2019_ e.pdf. Accessed 14 April 2020. 


\section{A. Y. Ylldız and H. Karaca}

14) Donis-González, I.R.; Bergman, S.M.; Sideli, G.M.; Slaughter, D.C.; Crisosto, C.H. Color vision system to assess English walnut(Juglans regia) kernel pellicle color. Postharvest Biol. Technol. 167, 111199 (2020).

15) Fuentealba, C.; Hernández, I.; Saa, S.; Toledo, L.; Burdiles, P.; Chirinos, R.; Campos, D.; Brown, P.; Pedreschi, R. Colour and in vitro quality attributes of walnuts from different growing conditions correlate with key precursors of primary and secondary metabolism. Food Chem. 232, 664-672 (2017).

16) Lee, J.; Vázquez-Araújo, L.; Adhikari, K.; Warmund, M.; Elmore, J. Volatile compounds in light, medium, and dark black walnut and their influence on the sensory aromatic profile. J. Food Sci. 76, 199-204(2011).

17) Bakkalbaşi, E.; Yilmaz, Ö.M.; Poyrazoğlu, E.S.; Artik, N. Tocopherol contents of walnut varieties grown in turkey and the effect of storage on tocopherol content. $J$. Food Process. Preserv. 38, 518-526 (2014).

18) Bakkalbaşi, E.; Yilmaz, Ö.M.; Yemiş, O.; Artik, N. Changes in the phenolic content and free radical-scavenging activity of vacuum packed walnut kernels during storage. Food Sci. Technol. Res. 19, 105-112 (2013).

19) Christopoulos, M.V.; Tsantili, E. Oil composition in stored walnut cultivars-quality and nutritional value. Eur. J. Lipid Sci. Technol. 117, 338-348(2015).

20) Hosseini, H.; Ghorbani, M.; Mahoonak, A.; Maghsoudlou, Y. Monitoring hydroperoxides formation as a measure of predicting walnut oxidative stability. Acta Aliment 43, 412-418 (2014).

21) Vidrih, R.; Hribar, J.; Solar, A.; Zlatić, E. The influence of atmosphere on the oxidation of ground walnut during storage at $20^{\circ} \mathrm{C}$. Food Technol. Biotechnol. 50, 454-460 (2012).

22) Mexis, S.F.; Badeka, A.V.; Riganakos, K.A.; Karakostas, K.X.; Kontominas, M.G. Effect of packaging and storage conditions on quality of shelled walnuts. Food Control 20, 743-751(2009).

23) Christopoulos, M.V.; Tsantili, E. Effects of temperature and packaging atmosphere on total antioxidants and colour of walnut (Juglans regia L.) kernels during storage. Sci. Hortic. (Amsterdam) 131, 49-57 (2011).

24) López, A.; Pique, M.T.; Romero, A.; Aleta, N. Influence of cold-storage conditions on the quality of unshelled walnuts. lnt. J. Refrig. 18, 544-549 (1995).

25) Tapia, M.I.; Sánchez-Morgado, J.R.; García-Parra, J.; Ramírez, R.; Hernández, T.; González-Gómez, D. Comparative study of the nutritional and bioactive compounds content of four walnut (Juglans regia L.) cultivars. J. Food Compos. Anal. 31, 232-237 (2013).

26) Zhang, Y.G.; Kan, H.; Chen, S.X.; Thakur, K.; Wang, S.; Zhang, J.G.; Shang, Y.F.; Wei, Z.J. Comparison of phenolic compounds extracted from Diaphragma juglandis fructus, walnut pellicle, and flowers of Juglans regia using methanol, ultrasonic wave, and enzyme assistedextraction. Food Chem. 321, 126672 (2020).

27) Dordoni, R.; Cantaboni, S.; Spigno, G. Walnut paste: oxidative stability and effect of grape skin extract addition. Heliyon 5, e02506 (2019).

28) AOCS. Official method Ca 5a-40: Free fatty acids. Official methods and recommended practices of the American Oil Chemists Society. AOCS Press, Champaign (2009).

29) AOCS. Official method Cd 8-53: Peroxide value acetic acid-chloroform method. Official methods and recommended practices of the American Oil Chemists Society. AOCS Press, Champaign (2003).

30) AOCS. Official Method Ch 5-91: Determination of specific extinction of oils and fats, ultraviolet absorption. Official methods and recommended practices of the American Oil Chemists Society. AOCS Press, Champaign (2001).

31) Bakkalbaşi, E.; Yilmaz, Ö.M.; Javidipour, I.; Artik, N. Effects of packaging materials, storage conditions and variety on oxidative stability of shelled walnuts. $L W T$ Food Sci. Technol. 46, 203-209(2012).

32) Singleton, V.L.; Orthofer, R.; Lamuela-Raventos, R.M. Analysis of total phenols and other oxidation substrates and antioxidants by means of Folin-Ciocalteu reagent. in Methods in enzymology (Lester, P. ed.) Academic Press, 299, 152-178 (1999).

33) Thaipong, K.; Boonprakob, U.; Crosby, K.; CisnerosZevallos, L.; Hawkins Byrne, D. Comparison of ABTS, DPPH, FRAP, and ORAC assays for estimating antioxidant activity from guava fruit extracts. J. Food Compos. Anal. 19, 669-675 (2006).

34) AOCS. Official Method Ce 8-89: Determination of tocopherols and tocotrienols in vegetable oils and fats by HPLC. Official methods and recommended practices of the American Oil Chemists Society. AOCS Press, Champaign (2009).

35) AOCS. Official Method Ce 2-66: Preparation of methyl esters of fatty acids. Official methods and recommended practices of the American Oil Chemists Society. AOCS Press, Champaign (1997).

36) Mokwena, K.K.; Tang, J. Ethylene vinyl alcohol: A review of barrier properties for packaging shelf stable foods. Crit. Rev. Food Sci. Nutr. 52, 640-650 (2012).

37) Jensen, P.N.; Sørensen, G.; Brockhoff, P.; Bertelsen, G. Investigation of packaging systems for shelled walnuts based on oxygen absorbers. J. Agric. Food Chem. 51, 4941-4947 (2003).

38) Mexis, S.F.; Badeka, A.V.; Kontominas, M.G. Quality evaluation of raw ground almond kernels (Prunus dulcis): Effect of active and modified atmosphere packaging, container oxygen barrier and storage conditions. Innov. Food Sci. Emerg. Technol. 10, 580589 (2009). 
39) Henríquez, C.; Loewe, V.; Saavedra, J.; Córdova, A.; Lutz, M. Effect of the type of packaging on the oxidative stability of pine nuts (Pinus pinea L.) grown in Chile. CYTA - J. Food 16, 255-262(2018).

40) Wang, S.; Monzon, M.; Johnson, J.A.; Mitcham, E.J.; Tang, J. Industrial-scale radio frequency treatments for insect control in walnuts. II: Insect mortality and product quality. Postharvest Biol. Technol. 45, 247253 (2007).

41) Padehban, L.; Ansari, S.; Koshani, R. Effect of packaging method, temperature and storage period on physicochemical and sensory properties of wild almond kernel. J. Food Sci. Technol. 55, 3408-3416(2018).

42) Evren, S. Storage stability of natural hazelnut flour. PhD Thesis, Institute of Science, Ondokuz Mayıs University, Samsun (2011).

43) Prescha, A.; Grajzer, M.; Dedyk, M.; Grajeta, H. The antioxidant activity and oxidative stability of coldpressed oils. J. Am. Oil Chem. Soc. 91, 1291-1301 (2014).

44) Buranasompob, A.; Tang, J.; Mao, R.; Swanson, B.G. Rancidity of walnuts and almonds affected by short time heat treatments for insect control. J. Food Process. Preserv. 27, 445-464(2003).

45) Lin, X.; Wu, J.; Zhu, R.; Chen, P.; Huang, G.; Li, Y.; Ye, N.; Huang, B.; Lai, Y.; Zhang, H.; Lin, W.; Lin, J.; Wang, Z.; Zhang, H.; Ruan, R. California almond shelf life: lipid deterioration during storage. J. Food Sci. 77, C583C593 (2012).

46) Belviso, S.; Dal Bello, B.; Giacosa, S.; Bertolino, M.; Ghirardello, D.; Giordano, M.; Rolle, L.; Gerbi, V.; Zeppa, G. Chemical, mechanical and sensory monitoring of hot air-and infrared-roasted hazelnuts (Corylus avellana L.) during nine months of storage. Food Chem. 217, 398-408(2017).

47) Turan, A. Effect of drying methods on fatty acid profile and oil oxidation of hazelnut oil during storage. Eur. Food Res. Technol. 244, 2181-2190(2018).

48) Huyan, Z.; Ding, S.; Mao, X.; Wu, C.; Yu, X. Effects of packaging materials on oxidative product formation in vegetable oils: Hydroperoxides and volatiles. Food Packag. Shelf Life 21, 100328(2019).

49) Ding, C.; Khir, R.; Pan, Z.; Zhao, L.; Tu, K.; El-Mashad, H.; McHugh, T.H. Improvement in shelf life of rough and brown rice using infrared radiation heating. Food Bioprocess Technol. 8, 1149-1159(2015).

50) Ghirardello, D.; Contessa, C.; Valentini, N.; Zeppa, G.; Rolle, L.; Gerbi, V.; Botta, R. Effect of storage conditions on chemical and physical characteristics of hazelnut (Corylus avellana L.). Postharvest Biol. Technol. 81, 37-43(2013).

51) Raisi, M.; Ghorbani, M.; Sadeghi Mahoonak, A.; Kashaninejad, M.; Hosseini, H. Effect of storage atmosphere and temperature on the oxidative stability of almond kernels during long term storage. J. Stored Prod. Res. 62, 16-21 (2015).

52) García-Pascual, P.; Mateos, M.; Carbonell, V.; Salazar, D.M. Influence of storage conditions on the quality of shelled and roasted almonds. Biosyst. Eng. 84, 201209 (2003).

53) Wilkin, J.D.; Ashton, I.P.; Fielding, L.M.; Tatham, A.S. Storage stability of whole and nibbed, conventional and high oleic peanuts (Arachis hypogeae L.). Food Bioprocess Technol. 7, 105-113(2014).

54) Villarreal-Lozoya, J.E.; Lombardini, L.; Cisneros-Zevallos, L. Electron-beam irradiation effects on phytochemical constituents and antioxidant capacity of pecan kernels [Carya illinoinensis (Wangenh.) K. Koch] during storage. J. Agric. Food Chem. 57, 1073210739 (2009).

55) Crowe, T.D.; Crowe, T.W.; Johnson, L.A.; White, P.J. Impact of extraction method on yield of lipid oxidation products from oxidized and unoxidized walnuts. $J$. Am. Oil Chem. Soc. 79, 453-456(2002).

56) Zajdenwerg, C.; Branco, G.F.; Alamed, J.; Decker, E.A.; Castro, I.A. Correlation between sensory and chemical markers in the evaluation of Brazil nut oxidative shelflife. Eur. Food Res. Technol. 233, 109-116(2011).

57) Cecchi, T.; De Marco, C.; Passamonti, P.; Pucciarelli, F. Analytical definition of the quality of extra-virgin olive oil stored in polyethylene terephthalate bottles. $J$. Food Lipids 13, 251-258(2006).

58) Poiana, M.A. Enhancing oxidative stability of sunflower oil during convective and microwave heating using grape seed extract. Int. J. Mol. Sci. 13, 9240-9259 (2012).

59) Labuckas, D.; Maestri, D.; Lamarque, A. Lipid and protein stability of partially defatted walnut flour ( Juglans regia L.) during storage. Int. J. Food Sci. Technol. 46, 1388-1397 (2011).

60) Martínez, M.; Barrionuevo, G.; Nepote, V.; Grosso, N.; Maestri, D. Sensory characterisation and oxidative stability of walnut oil. Int. J. Food Sci. Technol. 46, 1276-1281 (2011).

61) Miraliakbari, H.; Shahidi, F. Oxidative stability of tree nut oils. J. Agric. Food Chem. 56, 4751-4759 (2008).

62) Martínez, M.L.; Penci, M.C.; Ixtaina, V.; Ribotta, P.D.; Maestri, D. Effect of natural and synthetic antioxidants on the oxidative stability of walnut oil under different storage conditions. LWT - Food Sci. Technol. 51, 44-50 (2013).

63) Tinello, F.; Lante, A. Recent advances in controlling polyphenol oxidase activity of fruit and vegetable products. Innov. Food Sci. Emerg. Technol. 50, 73-83 (2018).

64) Ghirardello, D.; Bertolino, M.; Belviso, S.; Dal Bello, B.; Giordano, M.; Rolle, L.; Gerbi, V.; Antonucci, M.; Spigolon, N.; Zeppa, G. Phenolic composition, antioxidant 


\section{A. Y. Ylldız and H. Karaca}

capacity and hexanal content of hazelnuts (Corylus avellana L.) as affected by different storage conditions. Postharvest Biol. Technol. 112, 95-104(2016).

65) Bolling, B.W.; Blumberg, J.B.; Oliver Chen, C.Y. The influence of roasting, pasteurisation, and storage on the polyphenol content and antioxidant capacity of California almond skins. Food Chem. 123, 1040-1047 (2010).

66) Zamora, R.; Hidalgo, F.J. The triple defensive barrier of phenolic compounds against the lipid oxidation-induced damage in food products. Trends Food Sci. Technol. 54, 165-174(2016).

67) Arranz, S.; Pérez-Jiménez, J.; Saura-Calixto, F. Antioxidant capacity of walnut (Juglans regia L.) : Contribution of oil and defatted matter. Eur. Food Res. Technol. 227, 425-431 (2008).

68) Buthelezi, N.M.D.; Magwaza, L.S.; Tesfay, S.Z. Postharvest pre-storage processing improves antioxidants, nutritional and sensory quality of macadamia nuts. Sci. Hortic. (Amsterdam) 251, 197-208 (2019).

69) Manzocco, L.; Calligaris, S.; Mastrocola, D.; Nicoli, M.C. Antioxidant activity of polyphenol containing foods as affected by processing and storage conditions. in $D i$ etary anticarcinogens and antimutagens. Elsevier, pp. 235-237 (2000).

70) Nicoli, M.C.; Anese, M.; Parpinel, M. Influence of processing on the antioxidant properties of fruit and vegetables. Trends in Food Sci. Technol. 10, 94-100 (1999).

71) Huang, S.-W.; Frankel, E.N.; German, J.B. Antioxidant activity of $\alpha$ - and $\gamma$-tocopherols in bulk oils and in oilin-water emulsions. J. Agric. Food Chem. 42, 21082114(1994).

72) Li, L.; Tsao, R.; Yang, R.; Kramer, J.K.G.; Hernandez, M.
Fatty acid profiles, tocopherol contents, and antioxidant activities of heartnut (Juglans ailanthifolia var. cordiformis) and Persian walnut(Juglans regia L). J. Agric. Food Chem. 55, 1164-1169(2007).

73) Martínez, M.L.; Labuckas, D.O.; Lamarque, A.L.; Maestri, D.M. Walnut(Juglans regia L.): Genetic resources, chemistry, by-products. J. Sci. Food Agric. 90, 1959-1967 (2010).

74) Tzen, J.T.; Lie, G.C.; Huang, A.H. Characterization of the charged components and their topology on the surface of plant seed oil bodies. J. Biol. Chem. 267, 15626-15634 (1992).

75) Munné-Bosch, S.; Alegre, L. The function of tocopherols and tocotrienols in plants. CRC Crit. Rev. Plant Sci. 21, 31-57 (2002).

76) Hussain, N.; Irshad, F.; Jabeen, Z.; Shamsi, I.H.; Li, Z.; Jiang, L. Biosynthesis, structural, and functional attributes of tocopherols in planta; past, present, and future perspectives. J. Agric. Food Chem. 61, 61376149 (2013).

77) Mexis, S.F.; Kontominas, M.G. Effect of $\gamma$-irradiation on the physicochemical and sensory properties of walnuts (Juglans regia L.) . Eur Food Res Technol. 228, 823-831 (2009).

78) Maguire, L.S.; O’Sullivan, S.M.; Galvin, K.; O'Connor, T.P.; O’Brien, N.M. Fatty acid profile, tocopherol, squalene and phytosterol content of walnuts, almonds, peanuts, hazelnuts and the macadamia nut. Int. J. Food Sci. Nutr. 55, 171-178(2004).

79) Shahidi, F.; Wanasundara, U.N. Methods for measuring oxidative rancidity in fats and oils. in Food lipids: Chemistry, nutrition and biotechnology (Akoh, C.C.; Min, D.B. eds.). CRC Press, New York, pp. 387-388 (2008). 